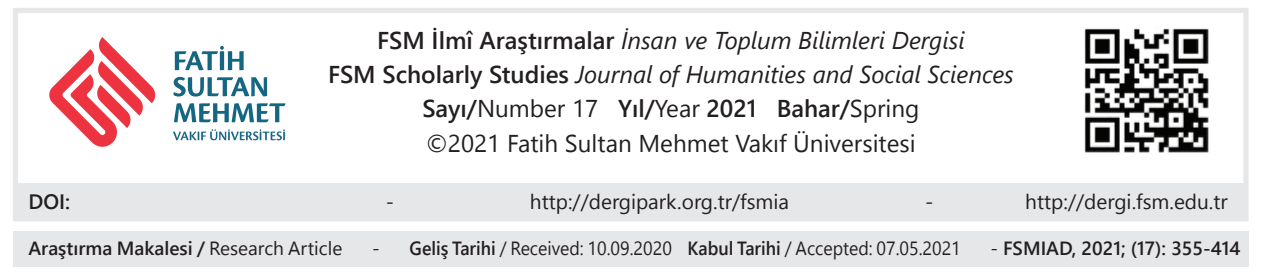

\title{
Kudüs'te Ebu Medyen El-Ğavs ve Şeyh Ömer El-Mücerred Vakıflarının Mali Durumu, 1855-1900
}

Şerife Eroğlu Memiş*

\section{Öz}

Ebu Medyen el-Ğavs'ın torunu Şuayb bin Muhammed bin el-Şuayb ve Şeyh Ömer el-Mücerred tarafından Meğaribe Mahallesi'nde kurulan vakıflar, Kudüs’te mukîm Mağribli Müslümanlar ile Mağribden gelen misâfir ve mücâvirlerin yeme-içme ve konaklama gibi çeşitli ihtiyaçlarını karşılamak üzere birer zâviye ihtiva etmekte idi. Gelirlerinin bir kısmını kırsal kaynaklardan elde eden bu vakıflar kentsel bazı gelirlere de sahipti. Hayrî ve mülhak bir yapıya sahip bu vakıflar şehir ekonomisi ile karşılıklı bir etkileşim halinde idi.Çalışma, vakıfların muhasebe defterlerini analiz ederek, kurumun 19. yüzyılın ikinci yarısındaki mali durumunu incelemektedir. Tarımsal ve kentsel gelirlerinde zaman zaman artışlar olan Ebu Medyen el-Ğavs ve Şeyh Ömer el-Mücerred Vakıfları,ilgili dönemde fiili işleyişini kesintiye uğratan bir mali bunalım döneminden geçmemiştir. Vakıfların mali durumu, kentsel koşulların vakıfları mali çöküntüye götürecek bir kötüleşme yaşamadığını da göstermiştir.

Anahtar Kelimeler: Ebu Medyen, Meğaribe, vakıf, Kudüs, muhasebe.

* Dr. Öğretim Üyesi, Ankara Hacı Bayram Veli Üniversitesi Edebiyat Fakültesi Tarih Bölümü, Ankara/Türkiye, serife_eroglu@yahoo.com, orcid.org/0000-0003-2880-8602 


\title{
Financial Situation of the Waqfs of Abu Madyan Al-Ghawth and Sheikh 'Umar Al-Mujarrad in Jerusalem, 1855-1900
}

\begin{abstract}
The waqfs, established by Abu Madyan Shuayb al-Maghribi,the grandson of Abu Madyan al-Ghawth, and Sheikh 'Umar al-Mujarrad, in the Maghariba neighborhood in Jerusalem, included one lodge each to meet the various needs of Maghribi Muslims residing in Jerusalem, as well as guests and adjacents from the Maghrib, such as eating, drinking and accommodation. These waqfs, which collected a part of their income from rural sources, also had some urban incomes. Those, which were among charitable endowments and managed by the persons stipulated in their waqfiyyas were in mutual interaction with the economic conditions in the city. This study is to analyze the financial situation of the institutions in the second half of the 19th century by analyzing the waqfs' accounting books. It reveals that while the agricultural and urban income of the waqfs increased from time to time, this did not bring about a period of financial crisis that interrupted their actual functioning. The financial situation of the waqf salso shows that the urban conditions did not deteriorate, which would lead to a financial collapse for both.
\end{abstract}

Keywords: Abu Madyan, Maghariba, waqf, Jerusalem, accounting. 


\section{Giriş}

Kudüs kenti vakıf ağının önemli bir bileşeni olarak Harem-i Şerif' in güneybatısında bulunan ve 1193 tarihinde Selahaddin Eyyubi'nin oğlu Melik Efdal tarafından vakıf olarak kurulan Meğâribe Mahallesi Vakfi, hem Kudüs'te mukîm olanlara hem de kenti ziyârete gelen Mağribli ${ }^{1}$ mücâvir ve misâfirlere kuruluşundan 1967'de kısmen ve 1969' da da tamamen yıkılışına kadar ev sahipliği yapmıştır. Zamanla Eyyûbîler ve Memlükler döneminde inşa edilen tarihsel ve kültürel açıdan önemli bir dizi yapının yerleşim alanı haline gelen vakıf mahalle, kadîm

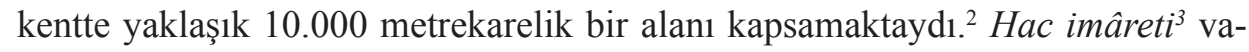
zifesi de gören ve Meğâribe Kapısı yakınında bulunan Ebu Medyen el-Ğavs ve Şeyh Ömer el-Mücerred zâviyeleri ile Meğâribe Camii, Fahriyye Medresesi ve Zâviyesi bunların başlıcalarıdır. 12. yüzyılın ikinci yarısında Melik Efdal tarafından inşa edilen ve Maliki fakihler için vakfedilen Efdaliyye Medresesi de mahalledeki önemli hayrât eserlerdendir. ${ }^{4}$

Kudüs'ün Osmanlılarca ilhakıyla beraber mahallede mevcut vakıf yapıları ihtiyaçlarına binaen tamir edilmiştir. Ayrıca yapılan denetimler ve görevli atamaları ile işlevselliği muhafaza edilmiştir. ${ }^{5}$ Bununla birlikte, Osmanlı döneminde de

1 Mahallenin tarihsel toponimisi Mağrib'den gelerek Kudüs'e yerleşmiş ya da Harem-i Şerif'i ziyaret eden, bu mahallede ikâmet eden göçmenler kaynaklıdır. Doğu İslam dünyasının (Maşrık) sınırı kabul edilen Mısır'dan Atlantik Okyanusu'na kadar uzanan Kuzey Afrika Bölgesi ve Güney Sahra, İslam kaynaklarında "Mağrib" adıyla anılmaktadır. Günümüzde bu coğrafyada Libya, Tunus, Cezayir, Fas ve Moritanya devletleri bulunmaktadır. Misır'ın batısında yer almasından dolayı bazı kaynaklarda Endülüs de Mağrib coğrafyasına dahil edilmektedir. Detaylı bilgi için bkz. İbrahim Harekât, "Mağrib" Mad., TDV İslam Ansiklopedisi, cilt 27, 2003, s. 313.

2 Abdüllatif Tibawi, The Islamic Pious Foundations in Jerusalem, Origins, History, and Usurpation by Israel, London, The Islamic Culture Centre, 1978, s. 10-12.

3 Kudüs'te bulunan Orta Asyalı ve Hintli sufi hacılara barınma ve yeme içme imkânı sağlayan Özbek, Afgan ve Hint tekkelerini "hâc imâretleri" olarak tanımlayan Zarcone, bu tekkeler aracılığı ile Orta Asya, Hindistan ve Osmanlı İmparatorluğu arasında ve Arap vilâyetleri özelinde gerçekleşen kültürel, dinsel ve siyâsî alışverişe dikkat çekmiştir. Thierry Zarcone, Kudüs 'teki Orta Asyalı ve Hintli Sufi Hacılar, İstanbul, Kabalcı Yay., 2012, s. 43-45. Meğaribe Mahallesi zâviyelerinin hac imaretleri olarak yüzyıllarca devam eden hizmetlerine ilişkin bir değerlendirme için bkz. Şerife Eroğlu Memiş, "Sürdürülebilir Gelişmede Vakıfların Tarihi Rolü: Ebû Medyen el-Ğavs Zâviyesi”, Keşkül Dergisi, sayı 46, 2018, s. 78-85.

4 Kudüs'e Kuzey Afrika'dan gelen fakihler Maliki idi. Bu nedenle de Meğâribe Mahallesi'nde bulunan medrese Maliki fakihler için uygundu. Donald P. Little, "Jerusalem under the Ayyubids and Mamluks, 1187-1516 AD”, içinde Jerusalem in History,ed. Kamil C. el-Aseli, Brooklyn, NY, 1990, s. 180.

5 Mahalleyi Osmanlı yönetimi döneminde çeşitli açılardan inceleyen çalışmalar için bkz. Hasan 
Meğâribe mahallesi sâkinleri tarafindan çok sayıda yeni vakıf kurulmuş, ancak mahallenin silüetine yeni yapılar eklenmemiştir. 17., 18. ve 20. yüzyıllarda, sırasıyla altı, on iki ve üç yeni vakıf kurulmuştur. Bunlardan üçü mahalle sakinlerinin yararına kurulmuş hayrî vakıf olup, birisi nuküd (para) vakfıdır. Geriye kalan on yedi vakıf ise mütevazı ve yerel olarak kurulmuş aile vakıflarıdır. ${ }^{6}$

Mahalle ve vakıflarına ilişkin çok sayıda çalışma kaleme alınmıştır. ${ }^{7}$ Mevcut çalışmalar çoğunluklamahallenin ve vakıflarının kuruluşu ya da 1967 yılında tahrip edilişi üzerinde yoğunlaşmıştır. Ancak son dönemlerde yapılan çalışmalar, mahallenin Osmanlı dönemindeki durumuna, tarihi gelişimine, sosyal yapısına, vakıflarına ilişkin bilgiler sunmuştur. ${ }^{8}$ Bununla birlikte mahalle ve vakıflarının tarih içerisinde, örneğin 19. yüzyıl veya Osmanlı'nın son yıllarında, geçirmiş oldukları değişimleri takip eden çalışmalara olan ihtiyaç devam etmektedir.Bu bağlamda, 19. yüzyılın ikinci yarısında Meğaribe Mahallesi ve Kudüs şehrinin iktisadi ve ticari yaşamında önemli bir yere sahip olan Ebu Medyen el-Ğavs ve Şeyh Ömer el-Mücerred Vakıfları'nın mali durumunun incelenmesi

Hüseyin Güneş, “Kudüs’te Bir Mahalle: Sekiz Yüz Y1llık Meğaribe Mahallesi ve Serencamı”, Vakıflar Dergisi, sayı 44, 2015, s. 9-35; Aynı yazar, Kudüs Meğaribe Mahallesi, Ankara, VGM Yay., 2017; Şerife Eroğlu Memiş, "Between Ottomanisation and Local Networks: Appointment Registers as Archival Sources for Waqf Studies. The Case of Jerusalem's Maghariba Neighborhood", Ordinary Jerusalem 1840-1940, Openning New Archives, Revisiting a Global City, ed. Angelos Dalachanis - Vincent Lemire, Leiden, Brill, 2018, s. 75-99; Ayn1 yazar, "18. Yüzyılda Kudüs ‘te Meğâribe Mahallesi Vakıflarının Yönetimi ve Görevli İstihdamı”, Journal of Islamicjerusalem Studies, cilt 17, say1 1, 2017, s. 37-69.

6 Mahallede kurulan vakıflara ait vakfiye listesi için bkz. Memiş, "Between Ottomanisation", s. 98-99.

7 Örn. bkz. Mucireddin el-'Uleymî el-Hanbelî, el-Unsü'l-celîl fî Târih-i Kuds ve'l-Halîl, cilt II, Amman, Mektebetu'1-Muhtesib, 1973, s. 45-46, 243; Adar Arnon, "The Quarters of Jerusalem in the Ottoman Period”, Middle Eastern Studies, vol. 28, no. 1, Jan. 1992, s. 1-65; Tibawi, a.g.e.; Tom Abowd, "The Moroccon Quarter: A History of the Present", Jerusalem Quarterly File (Institute of Jerusalem Studies), no. 7, 2000, s. 6-16; Muhammed Haşim Ğuşe, elEvkâfu'l-İslâmiyye fi'l-Kudsi'-ş-Şerîf: Dirâse Târihiyye Muvesseka, İstanbul, IRCICA, 2009; Irène Salenson and Vincent Lemire, "La destruction du quartier des Maghrébins: entre histoire, urbanisme et archéologie (1967-2007), Les Cahiers de l'Orient, 130, no. 2, Spring 2018, s. 129-46; Salim Tamari, "Waqf Endowments in the Old City of Jerusalem: Changing Status and Archival Sources", Ordinary Jerusalem 1840-1940, Openning New Archives, Revisiting a Global City, ed. Angelos Dalachanis - Vincent Lemire, Leiden, Brill, 2018, s. 506; Nazmi al-Jubeh, Hâret el-Yehud ve hâret el-Magharibe fî el-Kuds el-Kadîme: el-târîh ve el-masîr ma beyne el-tadmîr ve el-tahvîd, Beyrut, Institute for Palestine Studies, 2019; Maryvelma Smith O'Neil, "The Mughrabi Digital Archive and the Virtual Illes Relief Initiative", Jerusalem Quarterly, no. 81, 2020, s. 52-76. 
amaçlanmaktadır. Bunun için, vakfa ait yaklaşık yarım asırlık bir zaman dilimini kapsayacak şekilde çeşitli yıllara tarihlenen muhasebe kayıtları incelenecektir. Böylece, Kudüs'e Mağrib'den gelen Müslümanlar için yeme-içme ve barınma başta olmak üzere çeşitli hizmetler sunan Ebu Medyen el-Ğavs ve Şeyh Ömer el-Mücerred vakıflarının mali tarihinin detayları ortaya konularak, Kudüs şehri ve bölgesinin iktisadi tarihine yeni arşiv belgeleri ışı̆̆ında katkı sağlanması da amaçlanmaktadır. Vakfin çoğunlukla mahallede bulunan ev, dükkan, değirmen gibi akarlarından elde ettiği kira gelirleri ile şehir iktisadi hayatı arasında doğrudan sağlam bir ilişki bulunmaktadır. Zira şehirdeki iktisadi faaliyetlere yön veren temel hareketlilik şehrin dinî öneminden kaynaklanmaktayd. ${ }^{9}$ Şehri ziyaret eden hacıların, sûfîlerin ve seyyahların yeme, içme ve barınma gibi ihtiyaçlarının karşılanmasında, örneğin Mağrib'den gelenler için mahalle vakıflarına ait kiralık evler, odalar büyük önem arz etmekte idi. Bununla birlikte elde edilen sonuçların diğer vakıfların kentsel gelirlerinin analizi ve farklı kaynaklar ile birlikte gözden geçirilmesi faydalı olacaktır. Bu yöndeki çalışmalara bir temel oluşturması gayesi ile vakıf zâviyelere ait 1855-1900 y1lları arasında tespit ettiğimiz muhasebe kayıtlarının detayları sunulmuştur.

Bir vakfa ait muhasebe defterleri, o vakfin mali tarihini ortaya koyacak en önemli arşiv malzemesini teşkil etmektedir. ${ }^{10}$ Muhasebe defterleri vakfın genellikle bir tam yılı kapsayan her bir mali dönem içinde sahip olduğu gelir kaynakları

9 Yasemin Avc1, Değişim Sürecinde Bir Osmanlı Kenti, Kudüs(1890-1914), Ankara, Phoenix Yay., 2004, s. 22-23, 31-32; Jehoshua Ben-Arieh, Jerusalem in the 19th Century: The Old City, Yad Izhak Ben Zvi, St. Martin Publications, 1984, s. 392-394.

10 Muhasebe defterlerinin yapı ve içerikleri hakkında daha detaylı bilgi için bkz., Kayhan Orbay, "Structure and the Content of the Waqf Account Books as sources for Ottoman Economic and Institutional History", Turcica, Revue D'Etudes Turques, vol. 39, 2007, s.3-48. Daha önce Barkan tarafından yayınlanan bazı muhasebe defterlerinde, defterlerin yapı ve içerikleri ile ilgili açıklamalar yapılmış ve defterlerdeki bazı bilgi ve veriler de düzenlenerek karşılaştırmalı analizler sunulmuştur. Örneğin bkz. Ömer Lütfi Barkan, "İmaret Sitelerinin Kuruluş ve İşleyiş Tarzına Ait Araştırmalar”, İstanbul Üniversitesi İktisat Fakültesi Mecmuası, cilt 23, sayı 1-2, 1962-63, s. 284-89. Ayrıca bkz. Akif Erdoğdu, “Konya Mevlevi Dergâhı'nın Mali Kaynakları ve İdaresi Üzerine Düşünceler ve Belgeler”, Belgeler, cilt XVII, say1 21, 1996, s. 21, 41-70. Son dönemde yapılan bazı çalışmalarda ise kayıt tutuş usulleri çeşitli vakıf kayıt ve belgeleri üzerinden incelenmiştir. Örn. bkz. Oktay Güvemli - Batuhan Güvemli, "Osmanlı Kayıt Kültüründe Vakıf Muhasebesi ve Devlet Muhasebe Sistemi," Vakıflar Dergisi, sayı 46, 2016, s. 9-10; Muhammed Emin Durmuş - İsmail Bektaş, “Osmanlı'da Muhasebe Usulü ve Vakıf Muhasebe Kayıtları Okuma Kılavuzu”, PESA Uluslararası Sosyal Araştırmalar Dergisi, cilt 3, sayı 2, 2017, s. 198; Fatma Şensoy, “Ebubekir Paşa'nın İstanbul'daki Sibyan Mektebi ve Sebil Vakfı'nın 1867-68 Yıllarına Ait Muhasebe Defterleri Üzerinden Vakıflardaki Kayıt Düzeni ve Dinamik Yapı”, Akademik Incelemeler Dergisi, cilt 13, sayı 1, Sakarya 2018, s. 391-416. 
ve bunlardan elde ettiği gelirler ile yine aynı yılda vakfın tüm gider kalemlerini tasnif ederek kaydetmekte ve vakfın alacak ve borçlarının dökümünü de vermektedir. Böylece vakfın fiili işleyişini tespit etmek mümkün olmaktadır. Başka bir ifade ile vakfın mali gidişatı, tahsilat güçlükleri, kalan alacakları ve borçları, mali yıl sonu bütçe dengesi gibi pek çok detaya ulaşılabilmektedir. Ayrıca, muhasebe kayitlarının analiz edilmesi ile elde edilen veriler sayesinde vakfin üstlendiği hizmetleri yerine getirip getirmediği, maaşları ve aylıkları düzenli ödeyip ödeyemediği, zâviyede sunulan hizmetlerin devamlı olup olmadı̆̆ gibi soruların yanıtlarına da ulaşılabilmektedir. ${ }^{11}$ Kudüs'te bulunan Ebu Medyen elĞavs ve Şeyh Ömer el-Mücerred vakıflarının bu çalışmada incelediğimiz dönem olan 19. yüzyılın ikinci yarısına ait muhasebe kayıtlarının dijital kopyaları Kudüs yakınındaki Abû Dîs'te bulunan İhyâu 't-Turâs ve'ş-Şuûni'd-Dîniyye Müessesetu İhyâi 't-Turâs ve'l-Buhûsi'l-İslâmiyye Arşivi (İhyâu 't-Turâs)' dan temin edilmiştir. Çalışmada, vakıfların yıllık gelir-giderlerinin tutulduğu muhasebe defterleri başlıca başvuru kaynağı olmuştur. ${ }^{12}$ Vakfin mali görünümü ve işlemleri ile ilgili açıklamalar bu kayıtlar üzerinden yapılacaktır.

\section{Kudüs'te Ebu Medyen El-Ğavs ve Şeyh Ömer El-Mücerred Zâviyeleri}

Kudüs'te Meğâribe Mahallesi'nde yukarıda adları zikredilen ve vakıf olarak kurulan iki zâviye bulunmakta idi. Bu zâviyelerden ilki Ebu Medyen el-Ğavs'ın torunu Şuayb bin Muhammed bin el-Şuayb tarafından kurulmuş olup, "Ebu Medyen" ya da "Ebu Medyen el-Ğavs" olarak anılmakta idi. ${ }^{13}$ Ikincisinin bânisi ise Şeyh Ömer el-Mücerred idi. Her iki vakıf da Kudüs’te mukîm ya da Kudüs'e

11 Farklı bir yöntemle bir dizi muhasebe defterini analiz eden ve vakıfların mali analizini yerel iktisadi koşullar ile ilişkilendiren bazı çalışmalar için örneğin bkz., Suraiya Faroqhi, "Vakıf Administration in Sixteenth Century Konya, The Zaviye of Sadreddin-i Konevi", Journal of the Economic and Social History of the Orient, cilt XVII, say1 2, 1974, s.145-172; ayn yazar, "A Great Foundation in Difficulties: or some evidence on economic contraction in the Ottoman Empire of the mid-seventeenth century", Revue D'Histoire Magrebine, say1 47-48, 1987, 109 121; Kayhan Orbay, “16. ve 17. Yüzyıllarda Bursa Ekonomisi: Sultan Çelebi Mehmed Yeşil İmaret'inin Mali Tarihi (1553-1650)", A.Ü. Osmanlı Tarihi Araştırma ve Uygulama Merkezi (OTAM) Dergisi, sayı 22, Güz 2007, s. 125-158.

12 Detaylı bilgi için bkz. İhyâu't-Turâs, Kutu No:41, Dosya No: 3/5/28/1271/13; Kutu No: 06, Dosya No: 3/2/0/15/1318/13.

13 Ebu Medyen el-Ğavs (ö. 594/1197) ilmi ve cömertliği ile tanınan Endülüs-Mağribi topluluğunun önde gelen üyesiydi. Kuzey Afrika sufizminin gelişimsel döneminin en etkili kişisi olacak olan Ebu Medyen, daha sonraki biyografiler tarafından "Şeyhlerin Şeyhi, Ariflerin Efendisi" olarak adlandırılmıştır. Detaylı bir inceleme için bkz. Vincent J. Cornell, The Way of Abu Madyan, Doctrinal and Poetic Works of Abū Madyan Shu'ayb ibn al-Husayn al-Ansârī (c. 509/1115-16- 594/1198), Cambridge, The Islamic Texts Society, 1996, s. 10-11. 
misafir ya da mücâvir olarak gelen Mağribliler'in çeşitli ihtiyaçlarını karşılamak üzere kurulan hayrî vakıflardı. 29 Ramazan 720/ 2 Kasım 1320 tarihinde kurulan Ebu Medyen el-Ğavs Vakfı'na ait vakfiyenin bir nüshası Vakıflar Genel Müdürlüğü Arşivi'nde bulunmaktadır. ${ }^{14}$ İlmi ve hayırseverliği ile tanınan vâkıf, zâviyenin önemli gelir kaynağı olarak Kudüs beldesi köylerinden 'Ayn-1 Kârim köyünün gelirlerini tahsis etmiştir. İkinci gelir kaynağı olarak da, Kudüs-i Şerîf’te Ummü'l-Benât Köprüsü olarak bilinen Silsile Kapısı sınırında bulunan bir eyvân ve iki oda ve bir saha ve kendine mahsus bir mürtefak ve bu mürtefakın altında kemer yapılı bir mahzeni bulunan ve dört tarafının sınırları vakfiyede belirlenmiş evi vakfetmiştir.

Vakfiyede etraflıca tarif edilen hayır şartları ise şöyledir: Zâviyenin tâmir ve bakımının yapılarak, tâmirattan artan gelir ile öncelikle Receb, Şaban ve Ramazan aylarında mütevelli tarafından ekmek yaptırılacak ve bu ekmeği batıdan gelen ve Kudüs-i Şerîf'te mukîm bulunan kadın ve erkek bütün Mağribliler'e dağıtılacaktır. İkinci olarak, Meğâribe Mahallesi fakirlerine Ramazan ve Kurban bayramlarında ve mevlid-i şerîf okunduktan sonra yemek verilecektir. Üçüncü olarak, Mağrib'den gelen Meğâribe Mahallesi'nde sâkin olan ihtiyaç sahiplerine ve evvelden zâviyede mukîm bulunan Mağribliler’e soğuktan korunmak için elbise parası ödenilecektir. Son olarak da, bir Mağribli vefat ettiğinde ve cenaze ile ilgili olarak kefen ve diğer teçhizatları için sarf edilmek üzere ihtiyaç duyulan malzemelerin vakfın gelirlerinden karşılanacaktır. ${ }^{15}$

Şeyh Ömer el-Mücerred tarafindan vakfedilen ikinci zâviye ise, Kudüs'te mukîm Mağribli fakirlere ve Mağrib'den Beyt-i Mukaddes'e gelenlerin sâkin olmaları için 3 Rebiulevvel 703/15 Ekim 1303 tarihinde vakfedilmiştir. ${ }^{16}$ On altı adet hücreden oluşan zâviyenin giderleri için Meğâribe Mahallesi'nden üç ev akar olarak tahsis edilmiştir. Evlerin kira gelirleri ile zâviyenin çeşitli masrafları ile iki bayramda zâviyede okutulacak mevlid-i şerîf sonrasında verilen yemeğin masrafları karşılanacaktır. Vakfiyede ayrıca, bu şartlar yerine getirildikten sonra vakıf gelirlerinden bir şey artarsa onunla ekmek alınarak Recep, Şaban ve Ramazan aylarında Kudüs-i Şerîf'deki Meğâribe fakirlerine dağıtılacaktır. ${ }^{17}$

Kudüs'te bulunan Ebu Medyen el-Ğavs Vakfı'nın Gazze'de bulunan akarlarına ait gelir ve giderlerinin muhasebe kayıtlarına detaylı bir şekilde yazıldığg da

14 Vakıflar Genel Müdürlüğü Arşivi (VGMA), Defter No 583: Sayfa No 27/ Sıra No 20.

15 VGMA, Defter No 583: Sayfa No 27/ Sira No 20.

16 VGMA, Defter No 583: Sayfa No 28/ Sira No 21.

17 VGMA, Defter No 583: Sayfa No 27/ Sira No 20. 
görülmüştür. ${ }^{18} \mathrm{Bu}$ kayıtlardaki gelir ve giderler Kudüs’teki Ebu Medyen el-Ğavs ve Şeyh Ömer el-Mücerred Vakıfları muhasebeleri ile birlikte kaydedilmiştir. ${ }^{19}$ Hatta ilgili kayıtlardan Eski Gazze şehrinin ticari kasabası olan es-Sûk'un Derec Mahallesi'nde Kudüs'teki vakfa bağlı ikinci bir Ebu Medyen el-Ğavs Zâviyesi’nin olduğu anlaşılmaktadır. ${ }^{20}$

\section{Ebu Medyen El-Ğavs ve Şeyh Ömer El-Mücerred Vakıfları Muhasebe Kayıtları}

Nispeten az bilinen ve daha az çalışılan muhasebe defterlerini daha iyi kullanmak için öncelikle kayıtların yapılarını anlamak gerekir. Vakıf gelir ve giderlerine ilişkin hesap kayıtlarındaki rakamlar bu yazıdaki incelemenin temelini oluşturmaktadır. Bu nedenle vakıf gelir ve gider rakamlarının oluşturulması amaciyla bu dokümanda uygulanan vakıf muhasebe defterlerinin yapısı kısaca tanitılacaktır.

Muhasebe kayıtlarında dönemsellik ilkesi vardır. Mali dönem ilke olarak bir senedir. Ama ikinci bir prensip daha söz konusudur. Her mütevelli kendi döneminin muhasebesinden sorumludur. Bu nedenle görev değişikliklerinde süresi bir yıldan az veya aşkın muhasebeler ile karşılaşılabilir. Ana muhasebe defteri dönem içerisinde gerçekleşen tüm mali hareketlerin, gelir ve giderlerin toplulaştırılmış sonuçlarını kaydeder. ${ }^{21}$ Yıllık ana muhasebe kayıtları bazen kopyalandıkları merkeze havale edilir ve yerel tutulan hesabı çapraz kontrol etmek için başka bir müsvedde defteri tutulurdu. Bu hesap doğrulandıktan sonra, merkezde onaylanan ve arşivlenen nihai bir belge hazırlanırdi. ${ }^{22}$

Çalışma çerçevesinde tespit edilen ve 1272-1317/1855-1900 yılları arasını kapsayan 8 muhasebe kaydı incelenmiştir. Kayıtların tamamı Arapça olarak kaydedilmiştir. Kayıtlarda çoğunlukla "Ebî Medyen el-Ğavs Vakfi" ile "Ömer el-Mücerred Vakfi” ”ın gelir ve giderleri birlikte yazılmıştır.Yalnızca 1317/1899-

18 Gazze'de de Kudüs'teki Ebu Medyen el-Ğavs Vakfı'na bağlı başka bir zâviye ve bu zâviye etrafında Mağribliler'in yaşadığı ikinci bir Meğaribe Mahallesi'nin varlığına ilişkin tafsilatlı bir inceleme, "Geç Dönem Osmanlı Gazze'sinde Ebu Medyen el-Ğavs Zâviyesi Vakfı" başlığı altında yayınlanmak üzere farklı bir çalışmada değerlendirilmiştir.

19 Örn. bkz. İhyâu 't-Turâs Arşivi, Kutu No:41, Dosya No:3/5/28/1272/13.

20 Selim Arafat el-Mübeyyid, El-Binâyât el-Eseriyye el-İslâmiyye fî Gazze ve kıtâihâ,Kahire, elHay'a el-Misriyye el-‘Âmma li'l-Kitâb, 1987, s. 316.

21 Ömer L. Barkan, "Fatih Cami ve İmareti Tesislerinin 14891490- Y1llarına ait Muhasebe Bilançoları”, İstanbul Üniversitesi İktisat Fakültesi Mecmuası, cilt 23, say1 1-2, 1962-63, s. 300-301; Kayhan Orbay, "Structure and the Content", s. 8.

22 Orbay, "Structure and the Content of the Waqf Account Books", s. 12. 
1900 tarihli muhasebe kaydında vakıf adı "Ebu Medyen el-Ğavs Vakfi" olarak kaydedilmiştir. Vakıfların, yıllık olarak hazırlanan muhasebe kayıtları tasdik edilerek, merkeze havale edilmiştir.

Vakıfların yıllara göre gelir-gider durumu ile borç ve gelir fazlasının kaydedildiği yıllık muhasebe kayıtları şöyledir:

Tablo 1. Ebu Medyen Vakfi Mali Durumu,

1272-1317/1855-1900 (kuruş/para) ${ }^{23}$

\begin{tabular}{|l|l|l|l|r|}
\hline No & Yıl & Gelir & Gider & Bâkî (Kalan) \\
\hline 1 & $1272 / 1855-1856$ & 13.726 & $16.023,17$ & $2.297,17$ (Borç) \\
\hline 2 & $1275 / 1858-1859$ & 17.675 & $27.614,20$ & $9.939,2$ (Borç) \\
\hline 3 & $1276 / 1859-1860$ & 28.453 & 25.796 & 2.657 (Fazla) \\
\hline 4 & $1288 / 1871-1872$ & $37.679,10$ & $32.040,05$ & $5.639,05$ (Fazla) \\
\hline 5 & $1293 / 1876$ & $90.136,32$ & $57.893,10$ & $32.243,22$ (Fazla) \\
\hline 6 & $1295 / 1878$ & 51.946 & $43.754,25$ & $8.191,15$ (Fazla) \\
\hline 7 & $1316 / 1898-1899$ & 59.726 & $60.542,22$ & 816,22 (Borç) \\
\hline 8 & $1317 / 1899-1900$ & $72.083,10$ & $1.306,20$ & 1.222 (Borç) \\
\hline
\end{tabular}

Buna göre vakıf gelirleri yıllar içerisinde artarak 1293/1876 yılında en yüksek seviyeye ulaşmış, sonraki yıl düşmekle birlikte kısmi artışlar devam etmiştir. Vakfin en fazla gelir fazlasına sahip olduğu y1l da yine 1293/1876 y1lı olmuştur. Kayıtların dördünde vakıf borçlu olarak kaydedilmişken, dördünde de gelir fazlası yazılmıştır. Yüzyıl sonuna gelindiğinde ise vakıf, cari yılı borçlu olarak kapatmıştır.

\section{Vakfin Gelirleri}

Muhasebe kayıtlarındaki ilk kayıt vakfın gelirlerini içermektedir. Vakfın toplam geliri cari yılda beklenen gelir ile önceki yıla ait vakfın eski mütevellisinde kalan bakiyeden oluşmaktadır.

Tablo 2'de görüleceği üzere vakfın 1272/1855-1856 yılı muhasebe döneminde toplam geliri 13.726 kuruştur.

23 Bahse konu dosyada yaklaşık 76 belge bulunmaktadır. Vakfa ait muhasebe kayıtları da karışık bir şekilde ilgili dosyada muhafaza edilmiştir. Bkz. İhyâu't-Turâs Arşivi, Kutu No:41, Dosya No:3/5/28/1272/13. 
Tablo 2. Vakfin 1272/ 1855-1856 Y111 Gelirleri (Kuruş/Para)

\begin{tabular}{|c|c|c|c|}
\hline No & Türü & Kiracisı & Miktarı \\
\hline 1 & $\begin{array}{l}\text { Meğaribe Mahallesi’nde bulunan } \\
\text { musakkafâtın kira gelirleri Cümle } \\
\text { Aded } 29\end{array}$ & - & 2.750 \\
\hline 2 & Vakıf firının kira geliri & İbn-i Asam & 700 \\
\hline 3 & Vakıf değirmen kira geliri & Kasım Bûca & 700 \\
\hline 4 & $\begin{array}{l}\text { Meğaribe Mahallesi'nde bulunan } \\
\text { menzil kirası }\end{array}$ & Abu Mâcid & 200 \\
\hline 5 & Menzil & Mu'attal & 000 \\
\hline 6 & $\begin{array}{l}\text { Meğaribe Mahallesi’nde menzil } \\
\text { kiras1 }\end{array}$ & Mu'attal & 000 \\
\hline 7 & $\begin{array}{l}\text { Meğaribe Mahallesi'nde menzil } \\
\text { kiras1 }\end{array}$ & Ali Süleyman & 300 \\
\hline 8 & $\begin{array}{l}\text { Meğaribe Mahallesi’nde menzil } \\
\text { kiras1 }\end{array}$ & Mustafa Süleyman & 350 \\
\hline 9 & $\begin{array}{l}\text { Meğaribe Mahallesi’nde menzil } \\
\text { kiras1 }\end{array}$ & Ebu Abid & 280 \\
\hline 10 & İki dükkan kirası & - & 40 \\
\hline 11 & İki dükkan & Mu'attal & 000 \\
\hline 12 & Dellâlîn Çarşısı'nda menzil kirası & Yehud & 600 \\
\hline 13 & Büyük Çarşı içerisinde dükkan kirası & İbn-i Temr & 240 \\
\hline 14 & Dellâlîn Çarşısı'nda dükkan kirası & $\begin{array}{l}\text { El-Hac Ahmed el- } \\
\text { Mağribî }\end{array}$ & 140 \\
\hline 15 & Tekke menzili kirası & $\ldots$ & 250 \\
\hline 16 & $\begin{array}{l}\text { Meğaribe Mahallesi’nde menzil } \\
\text { kiras1 }\end{array}$ & Musa Tunûsî & 2.000 \\
\hline 17 & Nisıf menzil kirası & Murad es-Süleymanî & 550 \\
\hline 18 & Menzil kirası & Veled-i Rinova Yehudi & 700 \\
\hline 19 & Menzil kirası & Yehud & 570 \\
\hline 20 & Dükkan ve menzil kirası & Yehud & 500 \\
\hline 21 & Yahudi Mahallesi'ndeki evin kiras1 & - & 750 \\
\hline
\end{tabular}




\begin{tabular}{|c|c|c|c|}
\hline 22 & Söz konusu vakfa ait menzilin kirası & Evlâd-1 Ribaz & 800 \\
\hline 23 & Menzil hikr (mukâta'a) geliri & $\begin{array}{l}\text { El-Hac Mahmud } \\
\text { Efendi el-Halidî }\end{array}$ & 200 \\
\hline 24 & $\begin{array}{l}\text { Bab-1 Hutta Mahallesi’ndeki } \\
\text { menzilin kirası }\end{array}$ & Şeyh Muhammed İsa & 200 \\
\hline 25 & $\begin{array}{l}\text { Meğaribe Mahallesi’nde 1/3 iltizam } \\
\text { geliri }\end{array}$ & - & 800 \\
\hline 26 & $\begin{array}{l}\text { Meğaribe Kapısı'nda bulunan hakûre } \\
\text { (sebze bahçesi)nin geliri }\end{array}$ & Mu'attal & 000 \\
\hline 27 & $\begin{array}{l}\text { Silvan'da bulunan sebze bahçesi } \\
\text { geliri, Ramle'deki zeytinliğin nısıf } \\
\text { (1/2) geliri }\end{array}$ & & 6 \\
\hline 28 & $\begin{array}{l}\text { Rağıb el-İmam Şirketi’ne ait [12]72 } \\
\text { tarihli üzüm bağının kira geliri }\end{array}$ & Mu'attal & 0 \\
\hline 29 & $\begin{array}{l}\text { 'Ayn-1 Kârim karyesi gelirinden sene } \\
{[12] 72}\end{array}$ & Mu'attal & 0 \\
\hline
\end{tabular}

Tablo 2'de yer alan vakıf gelirleri incelendiğinde; vakfın musakkafât (üstü çatılı mülkler) türünden akarlarının çoğunlukla Meğâribe Mahallesi'nde olduğu görülmektedir. Bunun yanı sıra Dellâllar Çarşısı'nda bir ev ve bir dükkân, Büyük Çarşı'da bir dükkân, Yahudi Mahallesi'nde bir ev, Bâb-1 Hutta Mahallesi'nde bir ev ve Silvan'da bulunan sebze bahçesi vakfa gelir sağlayan diğer mahallerdeki akarlar olarak kaydedilmiştir.

Vakfın gelirleri arasında ilk olarak 29 kalemde kaydedilen vakıf musakkafâtınaait kira gelirleri 2.750 kuruş olarak tek kalemde kaydedilmişken, bu üstü çatılı yapıların nitelikleri belirtilmemiştir. Bunu 2.000 kuruş kira ile Musa el-Tunûsî tarafindan oturulan vakıf evin kirası takip etmiştir. Vakfın gelirleri arasında, Meğaribe Mahallesi'nde bulunan vakıf evlerin kira gelirlerinin yanı sıra,bir firın, bir değirmen ve beş dükkânın kira gelirleri de vardır. Vakfın cari yılda iki ev ve iki dükkânı da mu 'attal (boş) kalmıştır. Meğâribe Mahallesi'nde bulunan hakûre (sebze bahçesi) de ilgili cari yılda boş oluşu nedeniyle vakıf bütçesine katkı sağlamazken, Ramle'de bulunan sebze bahçesinin hikr ( $h u k r$, mukâta'a) geliri ise vakfın bütçesine oldukça cüz'i bir katkı sağlamıştır. Yine bahse konu cari yılda vakfın köyü olan 'Ayn-1 Kârim köyü akarları boş kalmıştır.

Vakıf musakkafâtında kiracı olarak kaydedilen kişilere bakıldığında ise; üç kiracının "Yehud" şeklinde kaydedildiği görülmüştür. Yahudi Mahallesi'nde olduğu belirtilen bir evde kimin sakin olduğu belirtilmemektedir. Öte yandan Me- 
ğaribe Mahallesi'ndeki kiraya verilen evlerin yıllar itibariyle sayılarındaki artışlar Yahudilerin "Ağlama Duvarı"na yakın olmak maksadıyla mahalledeki vakıf evlerden kiralamış olmaları ihtimalini de akla getirmektedir.

Çalışma çerçevesinde incelenen ve birbirini takip eden 1275/1858-59 y1lı Muharrem ayı başlangıcından itibaren1276/1859-60 yılı Zilhiccesi sonuna kadarki iki muhasebe kaydında vakıf gelirlerinin artarak devam ettiği görülmüştür. Vakfin 1275/1858-59 yılı kira geliri 17.045 kuruş olup, bu miktar sonraki muhasebe kaydında 19.953 kuruşa ulaşmıştır.

Tablo 3. Vakfin 1275/1858-59 ile 1276/1859-60 yılı gelirleri (Kuruş/Para)

\begin{tabular}{|c|c|c|c|c|}
\hline No & Akar Türü & Kiracı & Yilı & Miktarı \\
\hline \multirow[t]{2}{*}{1} & \multirow[t]{2}{*}{ Firın } & \multirow[t]{2}{*}{ İbn Zuheyman } & 75 & 750 \\
\hline & & & 76 & 1000 \\
\hline \multirow[t]{2}{*}{2} & \multirow[t]{2}{*}{ Değirmen } & \multirow[t]{2}{*}{ Ibn Bûca } & 75 & 750 \\
\hline & & & 76 & 700 \\
\hline \multirow[t]{2}{*}{3} & \multirow[t]{2}{*}{ Menzil } & \multirow[t]{2}{*}{ Ebu Macid } & 75 & 250 \\
\hline & & & 76 & 250 \\
\hline \multirow[t]{2}{*}{4} & \multirow[t]{2}{*}{ Menzil } & \multirow[t]{2}{*}{ El-Akkarî } & 75 & 700 \\
\hline & & & 76 & 800 \\
\hline \multirow[t]{2}{*}{5} & \multirow[t]{2}{*}{ Menzil } & \multirow[t]{2}{*}{ İbn Zelma, el-Yehudi } & 75 & 900 \\
\hline & & & 76 & 1200 \\
\hline \multirow[t]{2}{*}{6} & \multirow[t]{2}{*}{ Menzil } & \multirow[t]{2}{*}{ El-Hıyam Nesim } & 75 & 900 \\
\hline & & & 76 & 1200 \\
\hline \multirow[t]{2}{*}{7} & \multirow[t]{2}{*}{ Menzil } & \multirow[t]{2}{*}{ Dellâlîn } & 75 & 800 \\
\hline & & & 76 & 800 \\
\hline \multirow[t]{2}{*}{8} & \multirow[t]{2}{*}{ Menzil } & \multirow[t]{2}{*}{ Yehud } & 75 & 500 \\
\hline & & & 76 & 500 \\
\hline \multirow[t]{2}{*}{9} & \multirow[t]{2}{*}{ Menzil } & \multirow[t]{2}{*}{ Ali el-Bistâmî } & 75 & 330 \\
\hline & & & 76 & 600 \\
\hline \multirow[t]{2}{*}{10} & \multirow[t]{2}{*}{ Menzil } & \multirow[t]{2}{*}{ Yehud } & 75 & 700 \\
\hline & & & 76 & 900 \\
\hline \multirow[t]{2}{*}{11} & \multirow[t]{2}{*}{ Menzil } & \multirow[t]{2}{*}{ El-Akkar } & 75 & 450 \\
\hline & & & 76 & 450 \\
\hline \multirow[t]{2}{*}{12} & Değirmen & Hamûde & 75 & 220 \\
\hline & & & 76 & 220 \\
\hline
\end{tabular}




\begin{tabular}{|c|c|c|c|c|}
\hline \multirow[t]{2}{*}{13} & \multirow[t]{2}{*}{ Menzil } & \multirow[t]{2}{*}{-} & 75 & 362 \\
\hline & & & 76 & 400 \\
\hline \multirow[t]{2}{*}{14} & \multirow[t]{2}{*}{ Menzil } & \multirow[t]{2}{*}{-} & 75 & 2300 \\
\hline & & & 76 & 3000 \\
\hline \multirow[t]{2}{*}{15} & \multirow[t]{2}{*}{ Menzil } & \multirow[t]{2}{*}{ Ebu Mesud } & 75 & 300 \\
\hline & & & 76 & 400 \\
\hline \multirow[t]{2}{*}{16} & \multirow[t]{2}{*}{ Menzil } & \multirow[t]{2}{*}{ Ahmed Tutah } & 75 & 450 \\
\hline & & & 76 & 450 \\
\hline \multirow[t]{2}{*}{17} & \multirow[t]{2}{*}{ Dükkân } & \multirow[t]{2}{*}{ El-Mezmirî } & 75 & 100 \\
\hline & & & 76 & 180 \\
\hline \multirow[t]{2}{*}{18} & \multirow[t]{2}{*}{ Dükkân } & \multirow[t]{2}{*}{$\ldots$} & 75 & 60 \\
\hline & & & 76 & 60 \\
\hline \multirow[t]{2}{*}{19} & \multirow[t]{2}{*}{ Dükkân } & \multirow[t]{2}{*}{ El-Cum‘a } & 75 & 450 \\
\hline & & & 76 & 500 \\
\hline 20 & Dükkân & - & - & - \\
\hline \multirow[t]{2}{*}{21} & \multirow[t]{2}{*}{ Menzil } & \multirow[t]{2}{*}{ Ömer Ebu Mes`ud } & 75 & 500 \\
\hline & & & 76 & 500 \\
\hline \multirow[t]{2}{*}{22} & \multirow{2}{*}{$\begin{array}{l}\text { Meğâribe Mahalle- } \\
\text { si kiraları }\end{array}$} & \multirow[t]{2}{*}{-} & 75 & 1750 \\
\hline & & & 76 & 2500 \\
\hline \multirow[t]{2}{*}{23} & \multirow{2}{*}{$\begin{array}{l}\text { Meğâribe Mahal- } \\
\text { lesi'nde bulunan ... }\end{array}$} & & 75 & 1200 \\
\hline & & & 76 & 1000 \\
\hline \multirow[t]{2}{*}{24} & Menzil mukâta'ası & Seyyid Mahmud Efendi & 75 & 200 \\
\hline & & el-Hâlidî & 76 & 200 \\
\hline 25 & Dükkân & Es-Sûrî & 75 & 60 \\
\hline & & & 76 & 00 \\
\hline 26 & Dükkân & - & 75 & 60 \\
\hline & & & 76 & 60 \\
\hline 27 & Ev $(D a ̂ r r)$ & Bâbü'l-Bekâ'da & 75 & 333 \\
\hline & & & 76 & 333 \\
\hline 28 & Menzil & El-'Alemî & 75 & 600 \\
\hline & & & 76 & 600 \\
\hline 29 & Menzil & Ahvil & 75 & 400 \\
\hline & & & 76 & 400 \\
\hline
\end{tabular}




\begin{tabular}{|l|l|l|r|r|}
\hline 30 & Ev $($ Dâr $)$ & - & 75 & 250 \\
\cline { 3 - 5 } & & & 76 & 350 \\
\hline 31 & Ev (Dâr) & - & 75 & 400 \\
\hline 32 & \multirow{2}{*}{ Dükkân } & - & 76 & 400 \\
\cline { 3 - 5 } & & & 75 & 20 \\
\cline { 3 - 5 } & & & 76 & 00 \\
\hline
\end{tabular}

Tablo 3'te sunulan ve vakfin 1275/1858-59 ile 1276/1859-60 yıllarına ait gelirlerini gösteren muhasebe kayıtları kira miktarlarının değişimi ve kiracıların takip edilebilmesini mümkün kılmıştır. Her iki yılda da vakfa ait 32 musakkafât kaydedilmiştir. Öte yandan, birbirini takip eden bu muhasebe kayıtlarında yer alan gelir kalemleri incelendiğinde; büyük oranda kira gelirlerindeki artış vakıf gelirlerindeki artışın gerekçesi olarak görülmektedir. Her iki yıla ait muhasebe kay1tları Tablo 2'de sunulan ve 1272/1855-56 y1lına ait gelir kalemleri ile k1yaslandığında; vakfa ait boş olan ev ve dükkânlar kiraya verilmiş, yalnızca bir dükkân birbirini takip eden iki muhasebe kaydında boş kalmıştır. 1272/1855-56 y1lında bu boş dükkâna ek olarak, Silsile Mahallesi'nde olan ev ile mevki belirtilmeyen bir dükkân da boş kalmıştır. Yine de artan kira gelirleri nedeniyle 1276/1859-1860 y1lı gelirleri önceki yıla göre artmıştır. ${ }^{24}$

Çalışma çerçevesinde incelenen dördüncü muhasebe kaydı 1288/1871-72 yı11 Muharrem ayı başlangıcından Zilhicce ayı sonuna kadar bir yıllık dönemi kapsar. $\mathrm{Bu}$ yılda, vakfın gelirlerinde muazzam bir artış olmuş ve vakfın gelirleri neredeyse üç katına çıkmış ve vakıf gelir fazlası vermiştir. Vakfın gelirlerine ilişkin detaylar ise şöyledir:

Tablo 4. Vakfin 1288/1871-72 yıllarına ait gelirleri

\begin{tabular}{|l|l|l|r|}
\hline No & Vakfın Gelirleri & Kiracı & Ücret/Kuruş \\
\hline 1 & Dükkân - Silsile Mahallesi'nde & Mu'attal & 40 \\
\hline 2 & Dükkân - Silsile Mahallesi'nde & el-‘Anbâvî & 80 \\
\hline 3 & Dükkan-1 mahâziyye & el-Hac Ahmed & 350 \\
\hline 4 & Dükkân- Dellâllar Çarşısı'nda & el-Yehudi es-Sa‘âti & 200 \\
\hline 5 & Dükkân- Dellâllar Çarşısı'nda & el-Kendirci & 600 \\
\hline 6 & Dükkân- Dellâllar Çarşısı'nda & Abdullah Kutayna & 500 \\
\hline 7 & Dükkân- Yemekçiler (Tabh) Çarşısı'nda & Bekir el-Kutb & \\
\hline
\end{tabular}

24 İhyâu't-Turâs Arşivi, Kutu No: 41, Dosya No:3/5/28/1272/13. 


\begin{tabular}{|c|c|c|c|}
\hline 8 & Dükkan & - & \\
\hline 9 & Meğaribe Mahallesi’nde firın & - & 1200 \\
\hline 10 & Meğaribe Mahallesi'nde değirmen & El-A'zâbî & 850 \\
\hline 11 & $\begin{array}{l}\text { Meğaribe Mahallesi’nde değirmenin } \\
\text { önündeki evin kirası }\end{array}$ & El-A'rabî & 400 \\
\hline 12 & Meğaribe Mahallesi’nde ev & $\begin{array}{l}\text { Ebû Süleyman } \\
\text { (5 ay) }\end{array}$ & 125 \\
\hline 13 & Meğaribe Mahallesi’nde ev & Harim (7 ay) & 350 \\
\hline 14 & Meğaribe Mahallesi’nde ev & $\begin{array}{l}\text { el-Hac Said Ebu } \\
\text { Mesmûr }\end{array}$ & 500 \\
\hline 15 & Meğaribe Mahallesi'nde ev (1/3 hisseli) & Taha Abdurrahman & 160 \\
\hline 16 & Meğaribe Mahallesi’nde ev & $\begin{array}{l}\text { Evlâd-1 Ebu } \\
\text { Hamza }\end{array}$ & 500 \\
\hline 17 & Meğaribe Mahallesi'nde ev & $\begin{array}{l}\text { İbrahim el-Haceşe } \\
\text { (6 ay) }\end{array}$ & 200 \\
\hline 18 & Meğaribe Mahallesi’nde ev & .. & 250 \\
\hline 19 & Meğaribe Mahallesi’nde ev & İbn-i Mustafa & 600 \\
\hline 20 & Meğaribe Mahallesi’nde ev & Halîle & 600 \\
\hline 21 & Meğaribe Mahallesi'nde ev & Said Subhi & 500 \\
\hline 22 & Meğaribe Mahallesi’nde ev & $\begin{array}{l}\text { el-Mesmiyye bi- } \\
\text { dâr-1 el-Mezmizî } \\
\text { seken Zeliha } \\
\text { Hanım }\end{array}$ & 100 \\
\hline 23 & Meğaribe Mahallesi’nde ev & $\begin{array}{l}\text { el-Hac Ahmed } \\
\text { Tûtâc }\end{array}$ & 500 \\
\hline 24 & Meğaribe Mahallesi’nde ev & İbrahim ... & 500 \\
\hline 25 & Meğaribe Mahallesi’nde ev & Hazme & 220 \\
\hline 26 & Meğaribe Mahallesi'nde alt katta ahır & Mu'attal & - \\
\hline 27 & Meğaribe Mahallesi’nde ikinci ahır & $\begin{array}{l}\text { Mehmed es-Sâbî } \\
\text { (4 ay) }\end{array}$ & 28 \\
\hline 28 & Meğaribe Mahallesi'nde 5 evin kirası & $5 \mathrm{ev}$ & 2700 \\
\hline
\end{tabular}




\begin{tabular}{|c|c|c|c|}
\hline 29 & $\begin{array}{l}\text { Meğaribe Mahallesi’nde iki sebze } \\
\text { bahçesi kirası }\end{array}$ & 2 sebze bahçesi & 100 \\
\hline 30 & Meğaribe Mahallesi’nde ev & El-A'râbî & 100 \\
\hline 31 & Sebze bahçesi & - & \\
\hline 32 & Sebze bahçesi & - & 12 \\
\hline 33 & 3 kırat hisseli üzüm bağı kirası & - & 30 \\
\hline 34 & $\cdots$ & - & 380 \\
\hline 35 & $\begin{array}{l}\text { Yahudi Mahallesi'nde ev ve dükkân } \\
\text { kirası }\end{array}$ & Es-Siknaci & 1000 \\
\hline 36 & Yahudi Mahallesi’nde ev & - & 2500 \\
\hline 37 & Ermeni Mahallesi'nde ev & $\begin{array}{l}\text { Harim zeheb es- } \\
\text { Siknâcî }\end{array}$ & 1500 \\
\hline 38 & $\begin{array}{l}\text { Nasâra Mahallesi’nde yarım hisseli ev } \\
\text { kirası }\end{array}$ & Siknâcî (1,5 yıl) & 1211 \\
\hline 39 & Haddâdîn Mahallesi'nde ev & Nesir ve Neccâr & 1850 \\
\hline 40 & Vâd Mahallesi'nde ev & $\begin{array}{l}\text { Harim el- } \\
\text { Yehûdiyye }\end{array}$ & 600 \\
\hline 41 & $\begin{array}{l}\text { Hatt el-Bistâmiyye'de bulunan dükkan } \\
\text { kirası }\end{array}$ & Tekrûrî & 42 \\
\hline 42 & Ev & el-A'vânî & 600 \\
\hline 43 & Ahir & mu'attal & 0 \\
\hline 44 & $\begin{array}{l}\text { Bâb-I Hutta Mahallesi'nde alt katında } \\
\text { bulunan ahır ile birlikte ev kirası }\end{array}$ & 2,5 aydan beri & 125 \\
\hline 45 & $\begin{array}{l}\text { Ahır ve arkasında bulunan sebze } \\
\text { bahçesi kirası }\end{array}$ & el-Cevş & 125 \\
\hline 46 & Ev mukâta'ası (hikr-i dâr) & $\begin{array}{l}\text { el-Hac Mahmud } \\
\text { Efendi el-Hâlidî }\end{array}$ & 200 \\
\hline 47 & $\begin{array}{l}\text { Sebze bahçesi mukâta'ası (hikr-i } \\
\text { hakûre) }\end{array}$ & $\begin{array}{l}\text { evlâd-1 Ğanâmel- } \\
\text { Kâniyye el- } \\
\text { Cezâyirî }\end{array}$ & 0 \\
\hline 48 & $\begin{array}{l}\text { Hikr kıt'ati Erhayn Mihâil Râheyl bi- } \\
\text { takriyye 'Ayn-1 Kârim }\end{array}$ & 2 & 30 \\
\hline
\end{tabular}




\begin{tabular}{|c|c|c|c|}
\hline 49 & $\begin{array}{l}\text { Yakub’a satılan üzüm bağının hikr } \\
\text { geliri (Ne zaman parası alınırsa o } \\
\text { zaman hesaba girer.) }\end{array}$ & - & 0 \\
\hline 50 & $\begin{array}{l}\text { 'Ayn-1 Kârim arazisinde bulunan üzüm } \\
\text { bağının hikr geliri (Ne zaman parası } \\
\text { alınırsa o zaman hesaba girer.) }\end{array}$ & 1 & 0 \\
\hline 51 & $\begin{array}{l}\text { ‘Ayn-1 Kârim köyünde bulunan arsanın } \\
\text { Efrenc Kilisesi’nden alınacak olan } \\
\text { hikr geliri (Ne zaman parası alınırsa o } \\
\text { zaman hesaba girer.) }\end{array}$ & - & 0 \\
\hline 52 & $\begin{array}{l}2 \text { kit'a arsa icârı ‘Ayn-1 Kârim köyünde } \\
\text { bulunan ( } 86 \text { sonuna kadar } 4 \text { sene } \\
\text { müddetince) }\end{array}$ & $\mathrm{K}_{1} \mathrm{t}^{6} \mathrm{a} 2$ & 432 \\
\hline 53 & Dellâlların aidatı & - & 0 \\
\hline 54 & Gazze'de bulunan 4 dükkânın kirası & 4 & 168 \\
\hline 55 & Gazze'de bulunan 3 evin kiras1 & 3 & 225 \\
\hline 56 & $\begin{array}{l}\text { Gazze'de Beytü'l-İhya sahasında } \\
\text { bulunan Zehârine arsası }\end{array}$ & & 132 \\
\hline 57 & $\begin{array}{l}\text { Gazze'de Hacme Çarşısı'nda bulunan } \\
\text { ve Mesihiyyeden Bahaim'e satılan } \\
\text { hakûre }\end{array}$ & & 00 \\
\hline 58 & Gazze denizi arsasında diyane arsası & - & 0 \\
\hline 59 & Ramle'de bulunan bostan & 1 & 500 \\
\hline 60 & $\begin{array}{l}\text { Takârine Mahallesi'nde bulunan } \\
\text { meyveli ağaçların satışı }\end{array}$ & & 2370 \\
\hline 61 & $\begin{array}{l}\text { Dellâllar Çarşısı'nda bulunan Nesim el- } \\
\text { Yahudi tarafından oturulan evin kirası }\end{array}$ & 1 & 1725 \\
\hline 62 & $\begin{array}{l}\text { Yahudinin oturduğu Tabûne Derci } \\
\text { (Merdiven) arkasında bulunan evin } \\
\text { kirası }\end{array}$ & 1 & 1500 \\
\hline 63 & $\begin{array}{l}\text { Yahudi Mahallesi'nde bulunan ve Şeyh } \\
\text { Haydar'ın oturduğu evin kirası }\end{array}$ & 1 & 1200 \\
\hline
\end{tabular}


Buna göre vakfın önceki muhasebe defterlerinde kayıtlı kira geliri alınan ev sayısı 30'a çıkmıştır. İlaveten bir de yarım hisseli evin kira geliri de yine vakıf gelirleri arasındadır. Bunun yanı sıra henüz vakıf gelirlerine katılmamakla birlikte, gelirleri vakfa ait olan 'Ayn-1 Kârim köyündeki bazı arazilerden elde edilen mukâta'a gelirleri vakıf bütçesine katkı sağlamıştır. Bunlardan, ilki Mihâil Râheyl'den tahsil edilen mukâta'a geliri, ikincisi 'Ayn-1 Kârim köyünde bulunan 2 k1t'a arsanın kira geliridir.

1288/1871-72 y1lına ait muhasebe kaydında önceki muhasebelerden ayrı olarak Ebu Medyen el-Ğavs Vakfin'nın Gazze'de bulunan akar gelirlerinin de dahil edildiği görülmüştür. Gazze' de bulunan vakıf akarlar toplamda 7 ev ve 4 dükkânın kirası ile Gazze'de "Beytü'l-İhyâ" sahasında bulunan Zehârine arsasının kira geliri, Hacme Çarşısı'nda bulunan sebze bahçesi, Tekârine Mahallesi'nde bulunan meyveli ağaçların satış bedeli kaydedilmiştir.Vakfın Ramle'de bulunan bostanının kira geliri de bu gelirler arasında yazılmıştır.

Çalışma çerçevesinde incelenen daha erken tarihli muhasebe kayıtlarında yer almayan bir gelir kalemi olarak "dellâllar şeyhliği”" aidatı eklenmiştir. Mahallenin vakıflarının yönetim ve diğer görevlilerine ilişkin daha önce kaleme alınan bir incelemede; VGMA'da bulunan ve mahalledeki vakıflara yapılan görevli atamalarını ihtiva eden Hurûfât ve Atîk (eski) ve Cedîd (yeni) Hazîne Defterleri kayıtlarında mahallede vakfın mütevelli, nâzır ve türbedârı olan kişinin aynı zamanda da "şeyh-i dellâlân" olacağının kaydedildiği tespit edilmişti. ${ }^{25}$ Bahse konu atîk kayıtlarda "vakf-ı mezbûra her kim türbedâr ve mütevelli ve nâzır olur ise Kuds-i Şerif'in dellâllân meşîhati kadîmden beru meşrûtasıdır" notu yazılmıştı. ${ }^{26}$ Böylece, mahalle vakıflarının türbedâr, mütevelli ve nâzırı olan kişinin [günlük 7 akçe ile] aynı zamanda dellâllar şeyhliği makamının da sahibi olacağı kayıtlıdır. ${ }^{27}$ Dellâllar şeyhliği ise Kudüs kentinin 17. yüzyılda en faal loncaları arasındayd ${ }^{28}$ Bir mesleği ifade eden "dellâl" ismi "simsar," "arac1," yani "satıc1"gibi anlamları haiz olup, bu görevi yerine getiren lonca mensupları "çı̆̆ırtkanlık" yapmakta idi.Bu örgütlenmenin şeyhi de dellâllar şeyhi olarak anılmakta idi. Hem düzenli bir ücret, hem de loncanın her işleminden belirli bir pay alınması istisnai bir durum olup, dellâllar şeyhliğini diğerlerine göre daha kazançlı kılmakta idi. Bu sebeplerledir ki, 17. ve 18. yüzyılların de-

25 Memiş, “18. Yüzyılda Kudüs'te”, s. 45.

26 VGMA 515: 97/157.

27 VGMA 515: 97/157.

28 Amnon Cohen, Osmanlı Kudüs'ünde Loncalar, çev.N. Elhüseyni, İstanbul, Tarih Vakfı Yurt Yay., 2003, s. 172. 
ğişik yıllarında bu loncanın başına Mağribîler cemaatinin reisi geçmiştir. ${ }^{29} \mathrm{Bu}$ da yukarıda yer verilen muhasebe kaydının da işaret ettiği üzere vakfa ayrı bir gelir kalemi anlamına gelmekte idi.

Çalışma çerçevesinde incelenen beşinci muhasebe kayd1 1293/1876 tarihli kayıttır. $\mathrm{Bu}$ muhasebe kaydı, incelenen muhasebe kayıtları içerisinde vakfın en fazla gelir sağladığ 1 cari yıl olduğunu göstermiştir. 1288/1871-72 y1lı ile kıyaslandığında 37.679 kuruş 10 para olan vakıf geliri, 1293/1876 y1lında 90.136 kuruş 32 paraya yükselmiştir. 1293/1876 yılı muhasebe kaydında vakıf evlerden alınan kira gelirleri tek kalemde 2.200 kuruş olarak kaydedilmiştir. Bunun yanı sıra 11 dükkân kirası, 5 sebze bahçesi, bir değirmen, bir fırın ve beş de ahır kirası kaydedilmiştir. Önceki yıllara göre vakfın gelirlerinin yaklaşık 2,5 kat artmasının temel sebebi ise; önceki yıldan mütevelli elinde kalan gelir fazlasının vakfın gelirlerine dâhil olmasıdır. Bununla birlikte vakfın Gazze'deki akarlarının gelirler kısmı başında kaydedilen önceki yıldan devreden gelir fazlasının, üç aylık bir gelir fazlası olduğuna işaret etmiştir. Ancak bu gelir fazlası 23.158 kuruş olup, bu miktar örneğin vakfın 1272/1855-56 ile 1275/1858-59 y1llarına ait bütün gelirlerinden daha fazladır.

Öte yandan, vakfin kiralanan akar sayısındaki artışlar birkaç nedene bağlanabilir. Öncelikle çalışmanın giderler kısmında etraflıca inceleneceği üzere, vakıf evler başta olmak üzere vakfın akarlarının tamir ve bakımlarının vakıf giderleri arasında oldukça mühim bir paya sahip olduğu tespit edilmiştir. Örneğin bu sayı 1275/1858-59 y1lında 2 kalemde yazılmış iken, bu sayı 1293/1876 yılında 24'e, 1316/1898-99 yılında 32'ye çıkmıştır. ${ }^{30}$ Bu da tamir ve bakımı yapılan ev, dükkân vb. akarların kiraya verilmesi neticesinde kiralanan vakıf akar sayılarının artmış olabileceği düşüncesini akla getirmektedir. Bir diğer gerekçe de, vakıf ev ve dükkânların boş bırakılmış olması ihtimalidir. Bu konuda da yetki aynı zamanda da vakfiye şartı gereği Şeyhü'l-Meğaribe olan mütevelliye aitti. Son olarak da, vakıf akarlarının vakfın kuruluş amacına aykırı olarak kullanılmış olması ihtimali de yine olas1 gözükmektedir.

Vakfın 1293/1876 yılı gelirlerine ilişkin diğer detaylar ise şöyledir:

29 Cohen, a.g.e., s. 173.

30 Diğer muhasebe kayıtlarında yer alan tamir ve bakım harcama kalemlerine ilişkin detaylı inceleme için bkz. Tablo 12. 
Tablo 5. Vakfın 1293/1876 y1lına ait gelirleri

\begin{tabular}{|c|c|c|c|}
\hline No & Vakfin Gelirleri & Kiracı & $\begin{array}{r}\text { Ücret } \\
\text { (Kuruş/ } \\
\text { Para) }\end{array}$ \\
\hline 1 & $\begin{array}{l}\text { Vakfin [12]92 yılına ait gelir fazlası, } \\
\text { ki bu Gazze'den gönderilmiş ve } \\
\text { üç aylık Şevval başından Zilhicce } \\
\text { [1]293 y1lı sonuna kadar gönderilen } \\
\text { gelir fazlası }\end{array}$ & - & $23.158,32$ \\
\hline 2 & $\begin{array}{l}\text { Silsile Mahallesi'nde bulunan } \\
\text { dükkân }\end{array}$ & $\mathrm{Mu}$ 'attal & 000 \\
\hline 3 & $\begin{array}{l}\text { Silsile Mahallesi’nde bulunan } \\
\text { dükkân kirası }\end{array}$ & 'Anbâvî & 60 \\
\hline 4 & Dükkan kirası & El-Hac Ahmed Tutah & 80 \\
\hline 5 & $\begin{array}{l}\text { Dellâllar Çarşısı2nda bulunan } \\
\text { dükkânın kirası }\end{array}$ & Musa Kelde es-Siknâcî & 350 \\
\hline 6 & $\begin{array}{l}\text { Dellallar Çarşısı yakınında bulunan } \\
\text { dükkânın kirası }\end{array}$ & Aziz el-Kendirci & 200 \\
\hline 7 & $\begin{array}{l}\text { Dellallar Çarşısı'nda bulunan büyük } \\
\text { dükkânın kirası }\end{array}$ & Abdullah Kutayna & 600 \\
\hline 8 & $\begin{array}{l}\text { Nasara'da bulunan iki dükkanın } \\
\text { kirası }\end{array}$ & - & 000 \\
\hline 9 & $\begin{array}{l}\text { Meğaribe Mahallesi'nde bulunan } \\
\text { dükkânın kirası }\end{array}$ & Halil & 1500 \\
\hline 10 & $\begin{array}{l}\text { Meğaribe Mahallesi'nde bulunan } \\
\text { değirmenin kirası }\end{array}$ & Ağrabî & 1000 \\
\hline 11 & $\begin{array}{l}\text { Yemekçiler Çarşısı (As-sîk at-Tabh) } \\
\text { da bulunan dükkanın kirası }\end{array}$ & - & 600 \\
\hline 12 & $\begin{array}{l}\text { Meğaribe Mahallesi'nde bulunan } \\
\text { evin kirası }\end{array}$ & Ağrabî & 400 \\
\hline 13 & $\begin{array}{l}\text { Meğaribe Mahallesi'nde bulunan } \\
\text { evin kirası }\end{array}$ & Ebu Mazi & 300 \\
\hline 14 & $\begin{array}{l}\text { Meğaribe Mahallesi’nde bulunan } \\
\text { ve Şeyh Hasan makamı karşısında } \\
\text { bulunan evin kirası }\end{array}$ & - & 300 \\
\hline
\end{tabular}




\begin{tabular}{|c|c|c|c|}
\hline 15 & $\begin{array}{l}\text { Meğaribe Mahallesi'nde bulunan } \\
\text { evin kirası }\end{array}$ & el-Hac Said Abu Mes'ud & 500 \\
\hline 16 & $\begin{array}{l}\text { Meğaribe Mahallesi’nde bulunan } \\
\text { evin sülüs kirası }\end{array}$ & Taha al-A ğa & 160 \\
\hline 17 & $\begin{array}{l}\text { Meğaribe Mahallesi'nde bulunan } \\
\text { evin kirası }\end{array}$ & Emin Zağza & 600 \\
\hline 18 & $\begin{array}{l}\text { Meğaribe Mahallesi'nde bulunan } \\
\text { evin kirası }\end{array}$ & $\begin{array}{l}\text { Muhammed Ali et- } \\
\text { Terbakî }\end{array}$ & 400 \\
\hline 19 & $\begin{array}{l}\text { Meğaribe Mahallesi'nde bulunan } \\
\text { evin kirası }\end{array}$ & - & 000 \\
\hline 20 & $\begin{array}{l}\text { Meğaribe Mahallesi'nde bulunan } \\
\text { evin kirası }\end{array}$ & Kanber & 800 \\
\hline 21 & $\begin{array}{l}\text { Meğaribe Mahallesi'nde bulunan } \\
\text { evin kirası }\end{array}$ & Halile & 600 \\
\hline 22 & $\begin{array}{l}\text { Meğaribe Mahallesi'nde bulunan } \\
\text { evin kirası }\end{array}$ & Ali el-Bahşi & 600 \\
\hline 23 & $\begin{array}{l}\text { Meğaribe Mahallesi'nde bulunan } \\
\text { evin kirası }\end{array}$ & Said et-Tütüncü & 500 \\
\hline 24 & $\begin{array}{l}\text { Meğaribe Mahallesi'nde bulunan } \\
\text { evin kirası }\end{array}$ & el-Hac Ahmed Tutah & 500 \\
\hline 25 & $\begin{array}{l}\text { Meğaribe Mahallesi'nde bulunan } \\
\text { evin kirası }\end{array}$ & İbrahim el-Miha & 500 \\
\hline 26 & $\begin{array}{l}\text { Meğaribe Mahallesi'nde bulunan } \\
\text { evin kirası }\end{array}$ & - & 400 \\
\hline 27 & $\begin{array}{l}\text { Meğaribe Mahallesi'nde bulunan } \\
\text { tahtani bir ahır- }\end{array}$ & $\mathrm{Mu}^{\prime}$ attal & 000 \\
\hline 28 & $\begin{array}{l}\text { Meğaribe Mahallesi'nde bulunan } \\
\text { ikinci ahırın kirası }\end{array}$ & - & 90 \\
\hline 29 & $\begin{array}{l}\text { Meğaribe Mahallesi'nde bulunan } \\
\text { bütün odaların kiraları }\end{array}$ & - & 2200 \\
\hline 30 & $\begin{array}{l}\text { Meğaribe Mahallesi'nde bulunan } \\
\text { değirmen ve firın hizasında bulunan } \\
\text { iki kıt'a hakurenin kirası }\end{array}$ & - & 150 \\
\hline 31 & $\begin{array}{l}\text { Havâkir Kapısı'nda bulunan } \\
\text { hakurenin kirası }\end{array}$ & - & 150 \\
\hline
\end{tabular}




\begin{tabular}{|c|c|c|c|}
\hline 32 & $\begin{array}{l}\text { Meğaribe Kapısı karşısında bulunan } \\
\text { hakurenin kirası }\end{array}$ & - & 200 \\
\hline 33 & $\begin{array}{l}\text { Hakurenin karşısında Silvan'da } \\
\text { bulunan zeytin kiras1 }\end{array}$ & - & 11 \\
\hline 34 & $\begin{array}{l}\text { Bereket Sultan'dan önceki üzüm } \\
\text { bağı yakınında bulunan üç kıt'a } \\
\text { zeytin ücreti }\end{array}$ & - & 24 \\
\hline 35 & 1/4 üzüm bağ1 & - & 560 \\
\hline 36 & $\begin{array}{l}\text { Ramle'de bulunan bostan arsasının } \\
\text { ücreti }\end{array}$ & - & 500 \\
\hline 37 & $\begin{array}{l}\text { Meğaribe Mahallesi'nde bulunan } \\
\text { kaktüs hurmasının Ahmed Sutah'a } \\
\text { satılmasından elde edilen gelir }\end{array}$ & - & 1500 \\
\hline 38 & $\begin{array}{l}\text { Dellallar Çarşısı'nda bulunan evin } \\
\text { kirası }\end{array}$ & Nesim & 2000 \\
\hline 39 & $\begin{array}{l}\text { Tabune yokuşunda bulunan evin } \\
\text { kirası }\end{array}$ & Siknacı & 1900 \\
\hline 40 & $\begin{array}{l}\text { Şeyh Haydar hattında bulunan evin } \\
\text { kirası }\end{array}$ & Yahudi hanim el-Yaşar & 2000 \\
\hline 41 & Ev ve dükkanın kirası & İshak es-Siknaci & 1300 \\
\hline 42 & Ev kirası & - & 3000 \\
\hline 43 & $\begin{array}{l}\text { Ermeni Mahallesi'nde bulunan evin } \\
\text { kiras1 }\end{array}$ & Zeheb es-Siknaci & 1800 \\
\hline 44 & $\begin{array}{l}\text { Nasara Mahallesi'nde bulunan nısıf } \\
\text { hisseli evin kirası }\end{array}$ & Yohan Herş & 1300 \\
\hline 45 & $\begin{array}{l}\text { Haddadin Mahallesi'nde bulunan } \\
\text { evin kirası }\end{array}$ & Rum Kilisesi & 2200 \\
\hline 46 & $\begin{array}{l}\text { Vâd Mahallesi'nde bulunan evin } \\
\text { kirası }\end{array}$ & Yahudi & 800 \\
\hline 47 & $\begin{array}{l}\text { Bistami hattında bulunan dükkânın } \\
\text { kirası }\end{array}$ & Beyt Cüzuğ & 100 \\
\hline 48 & Ev kirası & Muhammed el-Bahari & 600 \\
\hline 49 & $\begin{array}{l}\text { Vakıf evin [altında] 1stabl (ahır) } \\
\text { kirası }\end{array}$ & Hüseyin el-Halil & 50 \\
\hline
\end{tabular}




\begin{tabular}{|c|c|c|c|}
\hline 50 & Bab-1 Hutta'da bulunan evin kiras1 & İbrahim Ağa Buzbaşı & 600 \\
\hline 51 & 1stabl ve hakurenin kirası & Bin Abu Farah & 125 \\
\hline 52 & $\begin{array}{l}\text { ‘Ayn-1 Kârim köyünün } 92 \text { senesi } \\
\text { Martından öşür bedelleri }\end{array}$ & - & 32.100 \\
\hline 53 & Ev hikr bedeli & $\begin{array}{l}\text { El-Hac Mahmud Efendi } \\
\text { el-Halidi }\end{array}$ & 200 \\
\hline 54 & Hakûrenin hikr bedeli & $\begin{array}{l}\text { Evlad-1 Ğanem el- } \\
\text { Cezâyiri }\end{array}$ & 000 \\
\hline 55 & Vakıf odaların hikr bedeli & Abdulkadir el-Halili & 000 \\
\hline 56 & Üç kırat hisseli evin hikr bedeli & Rum Kilisesi & 25,20 \\
\hline 57 & $\begin{array}{l}\text { ‘Ayn-1 Kârim köyünde bulunan iki } \\
\text { kıtâ arsanın } 92 \text { ve } 93 \text { yıllarına ait } \\
\text { hikr geliri }\end{array}$ & Mihail Raheyl & 60 \\
\hline 58 & $\begin{array}{l}\text { ‘Ayn-1 Kârim köyünde bulunan ve } \\
\text { Arşimendiyet tarafından satın alınan } \\
\text { üzüm bağçelerinin hikr geliri }\end{array}$ & Arşimendiyet & 000 \\
\hline 59 & $\begin{array}{l}\text { ‘Ayn-1 Kârim köyünde bulunan üzüm } \\
\text { bağ1 arsasının hikr geliri }\end{array}$ & - & 000 \\
\hline 60 & $\begin{array}{l}\text { ‘Ayn-1 Kârim köyünde bulunan ve } \\
\text { Efrenc Kilisesi tarafından kendi } \\
\text { mülkü sayıldığından beri hikr geliri }\end{array}$ & Efrenc Kilisesi & 000 \\
\hline 61 & $\begin{array}{l}\text { 'Ayn-1 Kârim köyünde bulunan ve } \\
\text { Sahyun rahipleri tarafından kendi } \\
\text { mülkü sayıldığından beri iki kıta } \\
\text { arsanın hikr geliri }\end{array}$ & Sahyun rahipleri & 000 \\
\hline 62 & $\begin{array}{l}\text { Dellâlbaşılık aidatı mîrî tarafından } \\
\text { mazbut olan gelir }\end{array}$ & - & 000 \\
\hline 63 & Gazze'de bulunan 4 dükkanın ücreti & - & 197 \\
\hline 64 & Gazze'de bulunan 3 evin ücreti & - & 275 \\
\hline 65 & $\begin{array}{l}\text { Gazze'de bulunan Zehârine arsasının } \\
\text { ücreti }\end{array}$ & - & 000 \\
\hline 66 & Gazze'de bulunan hakurenin ücreti & - & 000 \\
\hline
\end{tabular}

Buna göre; 1876 yılında vakfın kira geliri elde ettiği ev sayısı 22'ye, dükkân sayısı da 11'e ulaşmıştır. Bu sayıya Meğaribe Mahallesi'nde 1/3 hisseli ev ve Nasâra Mahallesi'nde bulunan $1 / 2$ hisseli evi de eklersek vakfa kira geliri geti- 
ren ev sayısı 24'e ulaşır.Gelir kalemleri arasında ciddi bir orana sahip Meğaribe Mahallesi'nde bulunan odaların toplam kira geliri 2.200 kuruş olmuştur. Bunun yanı sıra Meğaribe Mahallesi'nde bulunan bir değirmen, iki ahır, iki kıt'a sebze bahçesi, Havâkir Kapısı'ndaki sebze bahçesi, Meğaribe Kapısı karşısında bulunan sebze bahçesi, Silvan'da bulunan zeytin bahçesi, Bereket Sultan'da bulunan üzüm bağ1 yakınındaki zeytinlik, 1/4 hisseli üzüm băğ, Ramle'de bulunan bostanın kirası ve yine mahallede bulunan ahır ve sebze bahçesi vakfın gelirleri arasında kaydedilmiştir.

1292/1875 yılı başından itibaren 'Ayn-1 Kârim köyünün öşür gelirleri 32.100 kuruş olmuş ve önceki yıllarla kıyaslandığında vakıf gelirlerinde muazzam bir artışa sebep olmuştur. Bunun yanı sıra önceki yıllarda boş kalan vakıf arazilerin mukâta'a gelirleri ile köydeki zemini vakfa ait iki evin mukâta'a geliri de yine vakfın cari yıldaki diğer gelir kalemleri olarak kaydedilmiştir.

1293/1876 yılı önceki yıllara ait muhasebe kayıtları ile kıyaslandığında vakfa ait hem musakkafât nev'inden şehirde bulunan akarların gelirleri artarken, hem de vakfın köyü 'Ayn-1 Kârim'in öşür ve mukâta'a gelirleri vakıf bütçesine önemli gelir sağlamıştır.

Çalışma çerçevesinde incelenen 1295/1878 yılına ait altıncı muhasebe kaydında vakfın gelirleri azalmakla birlikte fazla vermeye devam ettiği görülmüştür. İlgili cari y1lın gelirleri şöyledir:

Tablo 6. Vakfin 1295/1878 y1lına ait gelirleri

\begin{tabular}{|l|l|l|r|}
\hline No & Gelirler & Kiracı & Ücret \\
\hline 1 & $\begin{array}{l}\text { "Fazla-i vakf sene [12]94 } \\
\text { 'alâ mütevelli" }\end{array}$ & - & 22.911 \\
\hline 2 & $\begin{array}{l}\text { MeğaribeMahallesi'nde } \\
\text { bulunan evin 295 yılına ait } \\
\text { kiras1 }\end{array}$ & Abdurrahman Efendi Hadûne & 1.425 \\
\hline 3 & $\begin{array}{l}\text { Dellâllar Çarşısı'nda bulu- } \\
\text { nan evin 295 yılı kirası }\end{array}$ & Şemuyil & 2.000 \\
\hline 4 & $\begin{array}{l}\text { Dercetü'l-Tabûne'de bulu- } \\
\text { nan alt kat evin 295 ve 296 } \\
\text { y1lları kirası }\end{array}$ & Savâ‘a es-Siknâci & 3.000 \\
\hline 5 & $\begin{array}{l}\text { Yahudi Mahallesi'nde alt } \\
\text { katta bulunan dükkan kiras1- } \\
\text { sene 95 }\end{array}$ & İshak es-Siknâcî & 1.300 \\
\hline
\end{tabular}




\begin{tabular}{|c|c|c|c|}
\hline 6 & $\begin{array}{l}\text { Yahudi Mahallesi'nde bulu- } \\
\text { nan evin kiras1 - sene } 295\end{array}$ & $\ldots$ & 2.500 \\
\hline 7 & $\begin{array}{l}\text { Ermeni Mahallesi'ndeki evin } \\
\text { kirasi-3 yıllıkGurre-i Muhar- } \\
\text { rem } 295 \text { y1lı başlangıcından } \\
297 \text { y1lı Zilhicesine kadar }\end{array}$ & Zeheb binti Şemuyil Şebîra & 4.500 \\
\hline 8 & $\begin{array}{l}\text { Yahudi Mahallesi'nde Şeyh } \\
\text { Haydar yakınında bulunan } \\
\text { evin kiras1- } 95 \text { ve } 96 \text { y1lla- } \\
\text { rına ait }\end{array}$ & Behur Şemuyil & 3.800 \\
\hline 9 & $\begin{array}{l}\text { Dâru'l-Hukûme tücâhında } \\
\text { bulunan evin kirası - sene } 95\end{array}$ & Yakub el-Muğzili el-Mûsevî & -- \\
\hline 10 & $\begin{array}{l}\text { Nasâra Mahallesi'nde bulu- } \\
\text { nan yarım hisseli vakıf evin } \\
\text { kiras1- } 10 \text { şehr min Rebi- } \\
\text { u's-Sani sene } 95\end{array}$ & Ali Efendi el-'Alemî & 600 \\
\hline \multirow[t]{2}{*}{11} & $\begin{array}{l}\text { İंcâr-1 dâr tücâhu kahve min } \\
\text { ğaye-i sene } 95\end{array}$ & Nur Muhammed & 600 \\
\hline & $\begin{array}{l}\text { Dellâllar Çarşısı'nda bulu- } \\
\text { nan büyük dükkanın kiras1- } \\
\text { sene } 95\end{array}$ & Abdülkadir el-Muhibbi el-Halilî & 600 \\
\hline 12 & $\begin{array}{l}\text { Dellâllar Çarşısı'nda bulu- } \\
\text { nan ikinci dükkanın kirası } \\
\text { - sene } 95\end{array}$ & Musa Kelde es-Siknâcî & 300 \\
\hline 13 & $\begin{array}{l}\text { Dellâllar Çarşısı'nda alt } \\
\text { katta bulunan evin kirası- } \\
\text { sene } 95\end{array}$ & 'Abriz es-Siknâcî & 200 \\
\hline 14 & $\begin{array}{l}\text { al-Battîh Çarşısı'nda bulu- } \\
\text { nan dükkanın kirası - sene } \\
95\end{array}$ & Hüseyin Ağnam & 450 \\
\hline 15 & $\begin{array}{l}\text { Silsile Çarşısı'nda bulunan } \\
\text { dükkan kirası - sene } 95\end{array}$ & $\cdots$ & 80 \\
\hline 16 & $\begin{array}{l}\text { Meğâribe Mahallesi'nde bu- } \\
\text { lunan firının kirası - sene } 95\end{array}$ & Halil eş-Şamî & 1.500 \\
\hline 17 & $\begin{array}{l}\text { Meğâribe Mahallesi'nde } \\
\text { bulunan değirmenin kiras1- } \\
\text { sene } 95\end{array}$ & El-A'rabî & 1.000 \\
\hline
\end{tabular}




\begin{tabular}{|c|c|c|c|}
\hline 18 & $\begin{array}{l}\text { İcâr-1 dâr tücâhu et-Tahûne } \\
\text { sene } 95\end{array}$ & El-A'rabî & 400 \\
\hline 19 & $\begin{array}{l}\text { Meğâribe Mahallesi’nde } \\
\text { Burak yakınında bulunan } \\
\text { evin kirası - sene } 95\end{array}$ & Şems Ebu Mes'ud & 500 \\
\hline 20 & $\begin{array}{l}\text { Meğâribe Mahallesi'nde } \\
\text { bulunan evin kirası - sene } 95\end{array}$ & Muhammed Ali el-mütevelli & 400 \\
\hline 21 & $\begin{array}{l}\text { Meğâribe Mahallesi'nde } \\
\text { bulunan evin kirası- sene } 95\end{array}$ & Süleyman es-Safat & 600 \\
\hline 22 & $\begin{array}{l}\text { Meğaribe Mahallesi'nde } \\
\text { bulunan "dâr er-Rummâne"- } \\
\text { kirası - sene } 295\end{array}$ & Halil eş-Şamî & 600 \\
\hline 23 & $\begin{array}{l}\text { Meğaribe Mahallesi’nde } \\
\text { bulunan evin kirası - sene } 95\end{array}$ & el-Hac Ahmed Tûta‘ & 500 \\
\hline 24 & $\begin{array}{l}\text { Merhûm el-Hac Mahmud } \\
\text { Efendi el-Halidî veresesin- } \\
\text { den alınan evin hikr geliri } \\
\text { sene } 95\end{array}$ & & 200 \\
\hline 25 & $\begin{array}{l}\text { Lud haricinde bulunan } \\
\text { zeytin bağının kira geliri } \\
\text { sene } 95\end{array}$ & & 350 \\
\hline 26 & $\begin{array}{l}\text { 'Ayn-1 Kârim köyünde bulu- } \\
\text { nan ve Latin Mihâil Raheyl } \\
\text { uhdesinde bulunan ev ve } \\
\text { arazinin hikr geliri }\end{array}$ & & 30 \\
\hline
\end{tabular}

Buna göre; muhasebe kaydında dikkati çeken ilk husus önceki cari yıldan mütevelli elinde kalan 22.911 kuruş bakiyye olmuştur. 13 ev, bir nısıf hisseli ev, 6 dükkân, bir firın, bir değirmen ve 'Ayn-1 Kârim'de bulunan iki evin mukâta'a gelirleri ile arsa ve Lud'da bulunan zeytin ağaçlarının kira gelirleri vakfin gelirleri olarak 26 kalemde 51.946 kuruş olarak kaydedilmiştir. 1293/1876 y1lı muhasebe kaydında 90.126 kuruş 12 para olan gelirlerin oldukça düştüğü görülmüştür. Bu da hem şehir merkezinde bulunan akarların say1larındaki ve kira gelirlerindeki düşüşe, hem de vakfın köyü 'Ayn-1 Kârim'in cüz'i katkısına bağlanabilir.

Çalışma çerçevesinde incelenen yedinci muhasebe kayd1 1326/1898-99 y1l1na aittir. Buna göre vakfın gelirleri şöyledir: 
Tablo 7. Vakfin 1316/1898-99 y1lına ait gelirleri

\begin{tabular}{|c|c|c|c|}
\hline No & Gelirler & Kiracı & Kuruş \\
\hline 1 & $\begin{array}{l}\text { Meğaribe Mahallesi'ndeki evin kira } \\
\text { geliri }\end{array}$ & eş-Şeyh Ali Ebu Macid & 337 \\
\hline 2 & $\begin{array}{l}\text { Meğaribe Mahallesi'ndeki evin kira } \\
\text { geliri }\end{array}$ & evlâd-1 Halîl & 583,10 \\
\hline 3 & $\begin{array}{l}\text { Meğaribe Mahallesi'ndeki evin kira } \\
\text { geliri }\end{array}$ & İsmail Betâsın & 726,20 \\
\hline 4 & $\begin{array}{l}\text { Meğaribe Mahallesi'ndeki evin kira } \\
\text { geliri }\end{array}$ & Ömer 'Ulvan & 625 \\
\hline 5 & $\begin{array}{l}\text { Meğaribe Mahallesi'ndeki evin kira } \\
\text { geliri }\end{array}$ & Ali en-Nattam & 416,20 \\
\hline 6 & $\begin{array}{l}\text { Meğaribe Mahallesi'ndeki evin kira } \\
\text { geliri }\end{array}$ & Ebu Şerif & 525,30 \\
\hline 7 & $\begin{array}{l}\text { Meğaribe Mahallesi'ndeki evin kira } \\
\text { geliri }\end{array}$ & $\begin{array}{l}\text { el-Hac Muhammed Za'- } \\
\text { zu }^{e}(\text { Zağzuğ })^{e}\end{array}$ & 300,30 \\
\hline 8 & $\begin{array}{l}\text { Meğaribe Mahallesi'ndeki evin kira } \\
\text { geliri }\end{array}$ & Abdülcevad es-Saka & 500 \\
\hline 9 & $\begin{array}{l}\text { Meğaribe Mahallesi'ndeki evin kira } \\
\text { geliri }\end{array}$ & el-Hurme Hadra & 228 \\
\hline 10 & $\begin{array}{l}\text { Meğaribe Mahallesi'ndeki değirme- } \\
\text { nin kira geliri }\end{array}$ & $\begin{array}{l}\text { es-Sahsah ve ibni el-Ma- } \\
\text { la'î }\end{array}$ & 750 \\
\hline 11 & $\begin{array}{l}\text { Meğaribe Mahallesi'ndeki fırının } \\
\text { kira geliri }\end{array}$ & $\begin{array}{l}\text { el-Hac Ahmed el-Mağri- } \\
\text { bi }\end{array}$ & $1.333,20$ \\
\hline 12 & $\begin{array}{l}\text { Meğaribe suru dişındaki sebze bah- } \\
\text { çesinin kira geliri }\end{array}$ & $\begin{array}{l}\text { el-Hac Hüseyin es-Sil- } \\
\text { vanî }\end{array}$ & 225 \\
\hline 13 & $\begin{array}{l}\text { Meğaribe suru içindeki sebze bahçe- } \\
\text { sinin kira geliri }\end{array}$ & eş-Şeyh Ali es-Silvanî & 166,20 \\
\hline 14 & $\begin{array}{l}\text { Fırın sathı civarında iki sebze bahçe- } \\
\text { sinin kira geliri }\end{array}$ & el-Hac Mübarek elinde & 295 \\
\hline 15 & $\begin{array}{l}\text { Meğaribe Mahallesi'ndeki evin kira } \\
\text { geliri }\end{array}$ & el-Hac Ahmed Tutah & 500 \\
\hline
\end{tabular}




\begin{tabular}{|c|c|c|c|}
\hline 16 & $\begin{array}{l}\text { Meğaribe Mahallesi'ndeki evin kira } \\
\text { geliri }\end{array}$ & Abdullah Tutah & 500 \\
\hline 17 & $\begin{array}{l}\text { Meğaribe Mahallesi'ndeki evin kira } \\
\text { geliri }\end{array}$ & İbrahim Hamîs & 583,10 \\
\hline 18 & $\begin{array}{l}\text { Meğaribe Mahallesi'ndeki evin kira } \\
\text { geliri }\end{array}$ & Reşid Ebu Mes'ud & 453,20 \\
\hline 19 & $\begin{array}{l}\text { Meğaribe Mahallesi'ndeki evin kira } \\
\text { geliri }\end{array}$ & el-Hac Derviş Siyâm & 635,30 \\
\hline 20 & $\begin{array}{l}\text { Meğaribe Mahallesi'ndeki evin kira } \\
\text { geliri }\end{array}$ & Selim er-Remlâvî & 431,20 \\
\hline 21 & $\begin{array}{l}\text { Meğaribe Mahallesi'ndeki evin kira } \\
\text { geliri }\end{array}$ & Abdullah Arif & 545 \\
\hline 22 & $\begin{array}{l}\text { Meğaribe Mahallesi'ndeki evin kira } \\
\text { geliri }\end{array}$ & es-Serih & 416,20 \\
\hline 23 & $\begin{array}{l}\text { Meğaribe Mahallesi'nde bulunan } \\
\text { evin kira geliri aylık } 10\end{array}$ & Ağrabi el-Halilî & 391,20 \\
\hline 24 & $\begin{array}{l}\text { Meğaribe Mahallesi'nde bulunan üç } \\
\text { buyût (odanın) kira geliri }\end{array}$ & Halil eş-Şerâbâtî & 450 \\
\hline 25 & $\begin{array}{l}\text { El-Sabra Ebi Ahmed Taha zamanın- } \\
\text { daki gelir }\end{array}$ & & $1.180,30$ \\
\hline 26 & $\begin{array}{l}\text { Bâb-1 Silsile'de bulunan dükkanın } \\
\text { kira geliri }\end{array}$ & Selim el-Harrâz & 135 \\
\hline 27 & $\begin{array}{l}\text { Bâb-1 Silsile'de bulunan dükkanın } \\
\text { kira geliri }\end{array}$ & El-Hac Ahmed Tûtah & 124,30 \\
\hline 28 & $\begin{array}{l}\text { Bâb-1 Silsile'de bulunan dükkanın } \\
\text { kira geliri }\end{array}$ & el-Yahudî el-Kendirci & 250 \\
\hline 29 & $\begin{array}{l}\text { Bâb-1 Silsile'de bulunan dükkanın } \\
\text { kira geliri }\end{array}$ & el-Yahudî es-Sâyiğ & 316,20 \\
\hline 30 & $\begin{array}{l}\text { Bâb-1 Silsile'de bulunan dükkanın } \\
\text { kira geliri }\end{array}$ & ibn-i Musa Ebû Akr & 666,20 \\
\hline 31 & $\begin{array}{l}\text { Hâdır Çarşısı'nda bulunan dükkanın } \\
\text { kira geliri }\end{array}$ & Ebî Ğuneym/Ğanim & 454,10 \\
\hline
\end{tabular}




\begin{tabular}{|c|c|c|c|}
\hline 32 & $\begin{array}{l}\text { Nasâra Mahallesi'nde bulunan evin } \\
\text { kira geliri }\end{array}$ & Deyri'r-Rûm & $1.453,10$ \\
\hline 33 & $\begin{array}{l}\text { Yahudi Mahallesi’nde bulunan evin, } \\
\text { dükkan ile birlikte kira geliri }\end{array}$ & & $2.166,25$ \\
\hline 34 & $\begin{array}{l}\text { Ermeni Mahallesi'nde bulunan evin } \\
\text { kira geliri }\end{array}$ & ez-Zehb es-Siknâciyye & 1.500 \\
\hline 35 & $\begin{array}{l}\text { Dercü’t-Tâbûnî’de bulunan evin kira } \\
\text { geliri }\end{array}$ & el-Yehûdî el-Akkâd & $1.833,20$ \\
\hline 36 & $\begin{array}{l}\text { Dellâlîn Çarşısı'nda bulunan evin } \\
\text { kira geliri }\end{array}$ & es-Sinâzî & $1.583,10$ \\
\hline 37 & Ev kira geliri & Ebi Bâruh eş-Şeyh Hisar & 1.500 \\
\hline 38 & $\begin{array}{l}\text { El-Lumâre el-Ufeyra ev ve altında } \\
\text { bulunan dükkanın kira geliri }\end{array}$ & Zeylak es-Siknâci & $1.458,10$ \\
\hline 39 & $\begin{array}{l}\text { Vâd Mahallesi’nde bulunan evin } \\
\text { kira geliri }\end{array}$ & Yakub es-Siknâci & 750 \\
\hline 40 & $\begin{array}{l}\text { Mağribî Kahvesi yakınında bulunan } \\
\text { evin kira geliri }\end{array}$ & Ali el-Afgânî & 666,20 \\
\hline 41 & $\begin{array}{l}\text { Mağribî Kahvesi yakınında bulunan } \\
\text { dükkânın kira geliri }\end{array}$ & Ahmed es-Semân & 181,20 \\
\hline 42 & $\begin{array}{l}\text { Mağribî Kahvesi yakınında bulunan } \\
\text { ahırın kira geliri }\end{array}$ & Kasım el-Muşaşa“ & 75 \\
\hline 43 & $\begin{array}{l}\text { Nasâra Mahallesi'nde evin kira } \\
\text { geliri }\end{array}$ & $\begin{array}{l}\text { Şeyh Abdurezzak el- } \\
\text { Alemi şirketi tarafindan } \\
\text { kullanılan }\end{array}$ & $2.361,20$ \\
\hline 44 & $\begin{array}{l}\text { Ramle'de bulunan bostan arsası kira } \\
\text { geliri }\end{array}$ & & $1.135,10$ \\
\hline 45 & Zeytin hasılâtı & & $1.364,20$ \\
\hline 46 & $\begin{array}{l}\text { Cûretü'l-'Inâb'da bulunan vakıf } \\
\text { zeytinlik hissesi kira geliri }\end{array}$ & & 48,20 \\
\hline 47 & $\begin{array}{l}\text { Meğaribe Mahallesi’nde bulunan } \\
\text { sülüs }(1 / 3) \text { hisseli evin kirası }\end{array}$ & Evlâd-1 Taha & 137,20 \\
\hline 48 & $\begin{array}{l}\text { Nasâra Mahallesi'nde bulunan hikr } \\
\text { hasılatı, } 301 \text { senesi başlangıcından } \\
313 \text { senesi sonuna kadar }\end{array}$ & $\begin{array}{l}\text { Şeyh Yusuf Fâhum } \\
\text { elinde bulunan }\end{array}$ & 562,20 \\
\hline
\end{tabular}




\begin{tabular}{|c|c|c|c|}
\hline 49 & $\begin{array}{l}\text { Nasâra Mahallesi'nde bulunan hikr } \\
\text { hasılatı, elinde bulunan } 301 \text { senesi } \\
\text { başlangıcından } 313 \text { senesi sonuna } \\
\text { kadar }\end{array}$ & $\begin{array}{l}\text { El-Pasi Erşid ve Kosta } \\
\text { Bişara }\end{array}$ & 1170 \\
\hline 50 & $\begin{array}{l}\text { Nasâra Mahallesi'nde bulunan hikr } \\
\text { hasılatı, } 301 \text { senesi başlangıcından } \\
313 \text { senesi sonuna kadar }\end{array}$ & Ebu Nuful yedinde, & 990 \\
\hline 51 & $\begin{array}{l}\text { 'Ayn-1 Kârim karyesinde } 1 \text { kit'a arsa } \\
\text { hikr bedeli }\end{array}$ & & 48 \\
\hline 52 & $\begin{array}{l}\text { 'Ayn-1 Kârim karyesinde bina inşası } \\
\text { hikr bedeli }\end{array}$ & & 90 \\
\hline 53 & $\begin{array}{l}\text { Latin Kilisesi'nden alınan kira geliri } \\
312 \text { 'den } 317 \text { senesine }\end{array}$ & & 75 \\
\hline 54 & $\begin{array}{l}\text { ‘Ayn-1 Kârim Köyünde bulunan } \\
\text { Latin Patriği’nden alınan kira geliri } \\
\text { 312'den } 317 \text { senesine }\end{array}$ & & 150 \\
\hline 55 & 'Ayn-1 Kârim köyü a'şar bedeli & & $20.416,30$ \\
\hline 56 & $\begin{array}{l}\text { Evkaf Sandığı'ndan 'Ayn-1 Kârim } \\
\text { köyü a'şar bedeli }\end{array}$ & & $3.431,10$ \\
\hline
\end{tabular}

Önceki muhasebe kaydı ile kıyaslandığında; vakfın geliri 51.946 kuruştan 59.726 kuruşa yükselmiştir. Yine önceki cari yılda 26 kalemde kaydedilen vakıf gelirleri 1316/1898-99 yılına 56 kalemde kaydedilmiştir. Vakfın Meğaribe Mahallesi'nde bulunan akarları ile diğer mahallerde olan akarları daha belirgin bir şekilde ayrı yazılmıştır. Buna göre vakfın Meğaribe Mahallesi’nde kira getiren 18 ev, odalar, 6 dükkân, bir değirmen, bir firın, dört sebze bahçesi bulunmakta idi. Önceki muhasebe kayıtlarından ayrı olarak vakfın mahalle dışındaki akarları da hem sayı hem de gelirleri bakımından artmıştır. Özellikle Nasâra Mahallesi'nde bulunan akarların kira gelirleri de fazladır. Bunun yanı sıra vakfın köyü olan 'Ayn-1 Kârim köyünden dört kalemde alınan 363 kuruş mukâta'a gelirleri ile 20.416 kuruş öşür gelirleri vakıf bütçesine kayda değer katkı sağlamıştır. Son olarak, önceki muhasebe kayıtlarında yer almayan "Evkaf Sandiğından 'Ayn-ı Kârim köyü a 'şar bedeli” başlığı altında ayrı bir kalemde evkaf sandığından alınan gelir eklenmiştir.

Çalışma çerçevesinde incelenen 1317/1899-1900 tarihli son muhasebe kaydında vakıf gelirleri artmaya devam etmiş ve 72.083 kuruş 10 para olarak ya- 
zılmıştır. Önceki yıla ait muhasebe kaydında olduğu gibi öncelikle Meğaribe Mahallesi'nde bulunan vakıf akarları, sonrasında diğer mahallerdeki akarlar kaydedilmiştir. Önceki kayıtlardan farklı olarak 'Ayn-1 Kârim köyünün öşür gelirleri yazlık ve kışlık olarak iki kalemde yazılmıştır. Bu da uygun iklim şartlarına bağlı olarak ilgili cari yılda iki hasat yapıldığını göstermektedir. Son olarak da "Vâridât-ı Zâviye-i Gazze" başlığı altında vakfın Gazze'de bulunan akarlarından elde edilen gelirleri altı kalemde kaydedilmiştir. Bunların detayları şöyledir:

Tablo 8. Vakfın 1317/1899-1900 y1lına ait gelirleri

\begin{tabular}{|l|l|l|r|}
\hline No & Gelirler & Kiracı & Kuruş \\
\hline 1 & Meğaribe Mahallesi'ndeki evin kirası & $\begin{array}{l}\text { eş-Şeyh Ali Ebu } \\
\text { Macid }\end{array}$ & 337 \\
\hline 2 & Meğaribe Mahallesi'ndeki evin kirası & evlâd-1 Halîlu & 583,10 \\
\hline 3 & Meğaribe Mahallesi'ndeki evin kirası & el-Hac Cum'a Salah & 625 \\
\hline 4 & Meğaribe Mahallesi'ndeki evin kirası & Ali en-Nattam & 450 \\
\hline 5 & Meğaribe Mahallesi'ndeki evin kirası & Ebu Şerif & 525,30 \\
\hline 6 & Meğaribe Mahallesi'ndeki evin kirası & $\begin{array}{l}\text { el-Hac Mehmed Za' } \\
\text { zu' (Zağzuğ) }\end{array}$ & 430,30 \\
\hline 7 & Meğaribe Mahallesi'ndeki evin kirası & Abdülcevad es-Saka & 500 \\
\hline 8 & Meğaribe Mahallesi'ndeki evin kirası & el-Hurme Hazre & 228 \\
\hline 9 & Meğaribe Mahallesi'ndeki evin kirası & el-Hac Ahmed Tutah & 500 \\
\hline 10 & Meğaribe Mahallesi'ndeki evin kirası & Abdullah Tutah & 500 \\
\hline 11 & Meğaribe Mahallesi'ndeki evin kirası & İbrahim Hamîs & 583,10 \\
\hline 12 & Meğaribe Mahallesi'ndeki evin kirası & Reşid Ebu Mes'ud & 453,20 \\
\hline 13 & Meğaribe Mahallesi'ndeki evin kirası & el-Hac Derviş Siyâm & 635,30 \\
\hline 14 & Meğaribe Mahallesi'ndeki evin kirası & Selim er-Remlâvî & 430,20 \\
\hline 15 & Meğaribe Mahallesi'ndeki evin kirası & Abdullah Arif & 545 \\
\hline 16 & $\begin{array}{l}\text { Meğaribe Mahallesi'nde bulunan üç } \\
\text { buyût (odanın) kira geliri }\end{array}$ & Halil eş-Şerâbâtî & 450 \\
\hline 17 & $\begin{array}{l}\text { Meğaribe Mahallesi'nde bulunan tâhûne } \\
\text { (değirmenin) kira geliri }\end{array}$ & es-Sahsahî & 750 \\
\hline
\end{tabular}




\begin{tabular}{|c|c|c|c|}
\hline 18 & $\begin{array}{l}\text { Meğaribe Mahallesi'nde bulunan firının } \\
\text { kira geliri }\end{array}$ & Musa el-Kazamânî & 1.000 \\
\hline 19 & $\begin{array}{l}\text { Sur dişında bulunan sebze bahçesinin } \\
\text { kira geliri }\end{array}$ & Hüseyin es-Silvânî & 225 \\
\hline 20 & $\begin{array}{l}\text { Sur içinde bulunan sebze bahçesinin } \\
\text { kira geliri }\end{array}$ & $\begin{array}{l}\text { eş-Şeyh Ali es-Sil- } \\
\text { vânî }\end{array}$ & 166,20 \\
\hline 21 & $\begin{array}{l}\text { Sur içinde bulunan sebze bahçesinin } \\
\text { kira geliri }\end{array}$ & el-Hac Mübârek & 295 \\
\hline 22 & $\begin{array}{l}\text { Meğaribe Mahallesi'nde bulunan beyt } \\
\text { (odanın) kira geliri }\end{array}$ & Arif el-Kürdî & 228 \\
\hline 23 & $\begin{array}{l}\text { Meğaribe Mahallesi'nde bulunan meyve } \\
\text { ağaçlarından alınan tımar bedeli }\end{array}$ & & 720 \\
\hline 24 & $\begin{array}{l}\text { Bâb-1 Silsile'de bulunan dükkanın kira } \\
\text { geliri }\end{array}$ & Selim el-Harrâz & 135 \\
\hline 25 & $\begin{array}{l}\text { Bâb-1 Silsile'de bulunan dükkanın kira } \\
\text { geliri }\end{array}$ & $\begin{array}{l}\text { El-Hac Ahmed } \\
\text { Tûtah }\end{array}$ & 135 \\
\hline 26 & $\begin{array}{l}\text { Bâb-1 Silsile'de bulunan dükkanın kira } \\
\text { geliri }\end{array}$ & $\begin{array}{l}\text { el-Yahudî el-Ken- } \\
\text { dirci }\end{array}$ & 250 \\
\hline 27 & $\begin{array}{l}\text { Bâb-1 Silsile'de bulunan dükkanın kira } \\
\text { geliri }\end{array}$ & el-Yahudî es-Sâyiğ & 316,20 \\
\hline 28 & $\begin{array}{l}\text { Bâb-1 Silsile'de bulunan dükkanın kira } \\
\text { geliri }\end{array}$ & ibn-i Ebû Akr & 708 \\
\hline 29 & $\begin{array}{l}\text { Hıdır Çarşısı'nda bulunan dükkanın kira } \\
\text { geliri }\end{array}$ & Ebî Ğuneym/Ğanim & 454,10 \\
\hline 30 & $\begin{array}{l}\text { Nasâra Mahallesi'nde bulunan evin kira } \\
\text { geliri }\end{array}$ & Deyri'r-Rûm & $1.453,10$ \\
\hline 31 & $\begin{array}{l}\text { Yahudi Mahallesi'nde bulunan evin kira } \\
\text { geliri }\end{array}$ & & $2.066,25$ \\
\hline 32 & $\begin{array}{l}\text { Ermeni Mahallesi'nde bulunan evin kira } \\
\text { geliri }\end{array}$ & $\begin{array}{l}\text { ez-Zehb es-Siknâ- } \\
\text { ciyye }\end{array}$ & 1500 \\
\hline 33 & $\begin{array}{l}\text { Dercü’t-Tâbûnî'de bulunan evin kira } \\
\text { geliri }\end{array}$ & $\begin{array}{l}\text { el-Yehûdî el-Mağri- } \\
\text { bî el-Akkâd }\end{array}$ & $1.833,20$ \\
\hline
\end{tabular}




\begin{tabular}{|c|c|c|c|}
\hline 34 & $\begin{array}{l}\text { Dellâlîn Çarşısı'nda bulunan evin kira } \\
\text { geliri }\end{array}$ & es-Sinâzî & $1.583,10$ \\
\hline 35 & Ev kira geliri & $\begin{array}{l}\text { Ebi Bâruh eş-Şeyh } \\
\text { Hisar }\end{array}$ & 1.500 \\
\hline 36 & $\begin{array}{l}\text { El-Lumâre el-Ufeyra evi ve altında } \\
\text { bulunan dükkanın kira geliri }\end{array}$ & Zeylak es-Siknâci & $1.458,10$ \\
\hline 37 & $\begin{array}{l}\text { Vâd Mahallesi'nde bulunan evin kira } \\
\text { geliri }\end{array}$ & Yakub es-Siknâci & 750 \\
\hline 38 & $\begin{array}{l}\text { Mağribi Kahvesi yakınında bulunan } \\
\text { evin kira geliri }\end{array}$ & Ali el-Afgânî & 666,20 \\
\hline 39 & $\begin{array}{l}\text { Mağribi Kahvesi yakınında bulunan } \\
\text { evin kira geliri }\end{array}$ & Ahmed es-Semân & 135 \\
\hline 40 & $\begin{array}{l}\text { Mağribi Kahvesi yakınında bulunan } \\
\text { ahırın kira geliri }\end{array}$ & Kasım el-Muşaşa‘ & 75 \\
\hline 41 & $\begin{array}{l}\text { Ramle'de bulunan bostan arsasının kira } \\
\text { geliri }\end{array}$ & & $1.135,10$ \\
\hline 42 & Lud'da bulunan zeytin hasılatı & & \\
\hline 43 & $\begin{array}{l}\text { Cûretü'l-'Inâb'da bulunan vakıf zeytin } \\
\text { hissesinin kira geliri }\end{array}$ & & 28,20 \\
\hline 44 & $\begin{array}{l}\text { Meğaribe Mahallesi’nde bulunan sülüs } \\
(1 / 3) \text { hisseli evin kira geliri }\end{array}$ & evlâd-1 taha & 137,20 \\
\hline 45 & $\begin{array}{l}\text { Silsile Kapısı'nda Şer'i Mahkeme yakı- } \\
\text { nındaki dükkanın kira geliri }\end{array}$ & Racül Mısrî fakir & 38 \\
\hline 46 & $\begin{array}{l}\text { Hutta Kapisı Mahallesi'nde bulunan } \\
\text { zuhr hasılı geliri }\end{array}$ & $\begin{array}{l}\text { Ebî Şemseddin } \\
\text { el-'Aselî }\end{array}$ & 90 \\
\hline 47 & $\begin{array}{l}\text { 'Ayn-1 Kârim köyü kışlık a'şar bedeli } \\
\text { Hicri } 315 \text { senesi Mart ayından } 317 \text { sene- } \\
\text { si sonuna değin }\end{array}$ & & 3.750 \\
\hline 48 & $\begin{array}{l}\text { 'Ayn-1 Kârim köyü yazlık a'şar bedeli } \\
\text { Hicri } 315 \text { senesi Mart ayından } 317 \text { sene- } \\
\text { si sonuna değin }\end{array}$ & & $13.499,20$ \\
\hline
\end{tabular}




\begin{tabular}{|l|l|l|r|}
\hline 49 & $\begin{array}{l}\text { Gazze } \\
\text { 4 dükkanın kira geliri Hicri [2]96 senesi } \\
\text { başlangıcından 317 senesi sonuna kadar }\end{array}$ & 10.724,35 \\
\hline 50 & $\begin{array}{l}\text { 3 evin kira geliri Hicri 96 senesi } \\
\text { başlangıcından 317 sonuna değin }\end{array}$ & $8.486,10$ \\
\hline 51 & $\begin{array}{l}3 \text { sebze bahçesinin kira geliri Hicri } \\
{[2] 96 \text { senesi başlangıcından 317 sonuna }} \\
\text { değin }\end{array}$ & $\begin{array}{l}\text { Sûk el-Hamîr (Hamîr Çarşıs1) arsasının } \\
\text { kira geliri }\end{array}$ & 298,20 \\
\hline 52 & $\begin{array}{l}\text { El-Bahr yolu üzerinde bulunan üzüm } \\
\text { bağının kira geliri Hicri 96 senesi } \\
\text { başlangıcından 317 sonuna değin }\end{array}$ & $\begin{array}{l}7.630,05 \\
\text { Ez-Zehârina arsasının kira geliri Hicri } \\
{[2] 96 \text { senesi başlangıcından 317 sonuna }} \\
\text { değin }\end{array}$ & $27.139,30$ \\
\hline 54 & & & \\
\hline
\end{tabular}

Buna göre; vakfın 1317/1899-1900 yılına ait muhasebe kaydında Meğaribe Mahallesi'nde kira geliri elde ettiği ev sayısı 16 ve toplam kira geliri de yaklaşı 7.552 kuruştur. Buna üç odanın 450 kuruş kira geliri de eklendiğinde 8.002 kuruşa ulaşır. Vakfın boş evi de bulunmamaktadır. Önceki muhasebe kayıtlarında olduğu gibi bir firın, bir değirmen, üç sebze bahçesi ile altı dükkân vakfin mahalledeki diğer akarları olarak kaydedilmiştir. Mahalle dışındaki dükkân ve evler ile bostan ve bahçeler de diğer gelir kalemleri olmuştur. 'Ayn-1 Kârim köyünün kışlık öşür bedeli 3.750 kuruş olurken, yazlık öşür bedeli 13.499 kuruş olmuştur. Yılda iki hasat yapılan köyde gelirler yaz döneminde oldukça artmıştır.

Gazze'de bulunan musakkafât gelirleri 4 dükkân ve 3 ev olacak şekilde 1296 yılı başlangıcından 1317 yılı sonuna kadar olan dönemi topluca kaydedilmiştir. Buna göre 4 dükkânın geliri 10.724 kuruş 35 para olurken, 3 evin toplam geliri 8.486 kuruş 10 para olmuştur. Buna karşılık örneğin 1293/1876 yılında Gazze'de bulunan dört dükkânın kira geliri 197 kuruş olmuşken, evlerin geliri 275 kuruş olagelmiş idi. 1317 yılında Gazze'de bulunan musakkafâtın gelirlerinin yaklaşık 21 yıllık toplu bir şekilde kaydedilmesi vakıf gelirlerinin ilgili cari yılda oldukça artmasına vesile olduğu görülmüştür. 


\section{Vakfin Giderleri}

Vakıfların mali durumu ve faaliyetleri hakkında güvenilir bilgiye ulaşabilmek için muhasebe kayıtlarında yer alan gelir ve gider kısımları birlikte analiz edilmelidir. Vakfa ait muhasebe kayıtlarında çoğunlukla "el-masârifât" başlığı altında vakfın giderleri sıralanmıştır. Bunlar arasında öncelikle vakfiye şartı gereği yerine getirilen hayır şartlarına harcanan giderler kaydedilmiştir. Tablo 9 ve 10'da görüleceği üzere vakıf tarafından yerine getirilen hayır şartları kayıtlarda etraflıca yazılmıştır. Sonrasında vakfa ait musakkafât nev'inden mülklerin tamir ve bakımlarına ilişkin gider detayları, tamiri yapılan evin mevkii ve sâkin olan kişilerin adları yazılmıştır. Muhasebe kayıtlarında görevlilerin ücretleri ile çeşitli satın alımlar veya hizmetler için harcanan paralar olmak üzere başlıca dört başl1kta gruplanabilecek vakıf giderleri kayıtlarda oldukça detaylı bir şekilde sunulmuştur. Bu kalemlerin ardından tahsil edilmemiş gelirler de harcama tarafında listelenmiştir. Ve son olarak hesap, vakıf bütçesinde kalan açık veya nakit ile dengelenmiştir.

Tablo 9. Ebu Medyen el-Ğavs ve Şeyh Ömer el-Mücerred vakıflarının muhasebe kayıtlarındaki giderleri (kuruş/para)

\begin{tabular}{|c|c|c|c|c|c|c|c|c|}
\hline Giderler & $\begin{array}{r}1272 / \\
1855-56\end{array}$ & $\begin{array}{r}1275 / \\
1858-59\end{array}$ & $\begin{array}{r}1276 / \\
1859- \\
60\end{array}$ & $\begin{array}{r}1288 / \\
1871-72\end{array}$ & $\begin{array}{r}1293 / \\
1876\end{array}$ & $\begin{array}{l}1295 / \\
1878\end{array}$ & $\begin{array}{r}1316 / \\
1898-99\end{array}$ & $\begin{array}{r}1317 \\
1899- \\
1900\end{array}$ \\
\hline $\begin{array}{l}\text { Hayır } \\
\text { Hizmetleri }\end{array}$ & $10.839,39$ & $10.943,3$ & 14.853 & 19.277 & $24.557,5$ & $21.594,05$ & $45.094,2$ & $46.135,4$ \\
\hline $\begin{array}{l}\text { Ta'mîr/ } \\
\text { Bakımlar }\end{array}$ & $4.061,5$ & 8.210 & 2.299 & $10.187,5$ & $31.449,20$ & 19.171 & $7.771,20$ & $3.726,25$ \\
\hline $\begin{array}{l}\text { Görevli } \\
\text { Ücretleri }\end{array}$ & 580 & 400 & 400 & 1.080 & 1.080 & 1.480 & 580 & $1.768,1$ \\
\hline $\begin{array}{l}\text { Diğer } \\
\text { Masraflar }\end{array}$ & 542,28 & 493 & 4.413 & $1.779,05$ & 526 & $1.908,95$ & $5.664,82$ & $2.295,7$ \\
\hline $\begin{array}{l}\text { Gazze'deki } \\
\text { Zâviye }\end{array}$ & - & - & - & - & - & - & - & $26.728,01$ \\
\hline
\end{tabular}

Tablo 9'de yer alan vakıf giderleri başlıca dört ayrı kalemde tasnif edilmiştir. Bütün yıllara ait gider kalemleri arasında vakfin yerine getirdiği hayır 
hizmetleri en yüksek paya sahip olmuştur. Bu da vakfın hayrî amaçla kuruluşuna bağlanabilir. Bunu gider kalemleri arasında ikinci sırada yazılan vakfin hayrât ve akarlarının tamir ve bakım giderleri takip etmiştir. Görevli ücretleri düzenli bir şekilde her yıl kaydedilmiş olmakla birlikte vakıf giderleri arasında oldukça küçük bir orana sahip olmuştur. Vakıf giderleri arasında dördüncü olarak kaydedilen diğer masraflar başlığı altında sınıflandırılan kısımda çeşitli gider kalemleri kaydedilmiştir. Vakıf zâviyelerin masrafları ile bazı arsalara ait hikr bedeli, çeşitli vergiler, muhasebe harcı ve maaşı gibi kalemler bu başlıkta değerlendirilmiştir. Gazze'de bulunan zâviyenin giderlerinin toplu bir şekilde kaydedildiği 1317/1899-1900 tarihli son muhasebe kaydında vakfın diğer masraflar kalemleri oldukça yüksek çıkmıştır. Bu gider kalemi ilk yedi kayıtta diğer giderler arasında kaydedilmişken, vakfa ait ayrı bir başlıkta topluca kaydedilmiştir. Bu nedenle tablonun sonuna eklenmiştir. Çalışmanın bu bölümünde bahse konu gider kalemleri sırası ile incelenecektir.

\section{Zâviye ve Hayır Şartları Giderleri}

Ebu Medyen el-Ğavs'in torunu Şuayb bin Muhammed bin el-Şuayb ve Şeyh Ömer el-Mücerred tarafindan kurulan vakıflara ait yukarıda kısaca bahsedilen vakfiyelerde belirtilen hayır şartları Osmanlı yönetiminin son günlerine kadar yerine getirilmeye devam edilmiştir. Vakfa âit muhasebe kayıtlarında ilgili cari yıllarda çeşitli oranlarda bütçe kalemleri arasında açık eksiltme "münâkasa"usûlü ile temin edilen ve Receb, Şaban ve Ramazan aylarında fakirlere dağıtılan ekmek, mevlüd okutulması ve sonrasında ikram edilen yemek, Ramazan ve Kurban bayramlarında verilen yemek, fakir Mağribliler'e dağıtılan elbise, kumaş ve ayakkabı, kış aylarında fakir Mağribliler'e verilen kömür parası ile kimsesiz vefat eden Mağribliler'in cenaze masrafları kaydedilmiştir. Bunların yanı sıra yetim, miskin ve kimsesizlerin konaklaması için kiralanan evlere ait kira gideri, Kudüs'e gelen Mağribli ziyaretçilerin kalmaları için kiralanan oda masrafları ve dönüşlerinde kendilerine verilen yolluk masrafları yine bütçe kalemlerinde zikredilen diğer hayır amaçlı vakıf hizmetleridir. Böylece mahalle vakıfları, vakfiye şartları çerçevesinde yüzyıllar boyunca mahallenin yoksulları için kalıcı ve kimseye muhtaç olmadan bir yaşam sürdürebilmeleri ve yoksulluk ve güvenlik sorunlarıla mücadelede toplumun kalkınması anlamında devleti destekleyici tarihsel bir rol üstlenmiştir. ${ }^{31}$ Vakfa ait 1272/1855-56 tarihli muhasebe kaydında kayıtlı hayır şartlarının detayları ise şöyledir:

31 Memiş, "Sürdürülebilir Gelişmede”, s. 78-85. 
Tablo 10. 1272/1855-56 tarihli muhasebe kaydında kayıtlı vakıf hayır hizmetleri (kuruş/para)

\begin{tabular}{|c|l|r|}
\hline No & Hayır Hizmetinin Niteliği & Masraflar \\
\hline 1 & Mevlid-i Şerîf’te mücâvirîne verilen yemeğin masrafı & 290 \\
\hline 2 & Receb-Şaban-Ramazan aylarında dağıtılan ekmek masrafı & $5.613,19$ \\
\hline 3 & Ramazan Bayramı'nda mücâvirîne verilen yemeğin ücreti & 305 \\
\hline 4 & Kurban Bayramı'nda mücâvirîne verilen yemeğin ücreti & 324 \\
\hline 5 & $\begin{array}{l}\text { Kiş mevisiminde mahalledeki mücâvirler için kömür, } \\
\text { ayakkabı ve elbise ücreti }\end{array}$ & 505 \\
\hline 6 & $\begin{array}{l}\text { Meğaribe Mahallesi fakirleri ve misafirlerinin Kudüs'ü } \\
\text { ziyaretlerindeki yemeklerin masrafı }\end{array}$ & $3.742,20$ \\
\hline 7 & $\begin{array}{l}\text { Ramazan'da 'Ayn-1 Kârim köyü şeyhleri için yemek } \\
\text { masrafı }\end{array}$ & $\mathbf{1 0 . 8 3 9 , 3 9}$ \\
\hline Toplam & &
\end{tabular}

Tablo 10'da yer alan harcama kalemleri incelendiğinde; gider kalemleri arasında en fazla gider 5.613 kuruş 19 para ile Receb-Şaban-Ramazan aylarında fakir Mağriblilere dağıtılan ekmek masrafi olmuştur. Bunu 3.742 kuruş 20 para ile Meğaribe Mahallesi fakirleri ve misafirlerinin Kudüs'ü ziyaretlerindeki yemeklerin masrafi takip etmiştir. Diğer harcama kalemleri de çoğunlukla vakfiye şartı gereği yerine getirilen diğer yemek masraflarıdır. Bu da zâviyelerin birer imâret gibi faaliyette bulunduklarına işaret etmektedir.

Çalışma çerçevesinde incelenen muhasebe kayıtlarında kayıtlı hayır hizmetlerinin neler olduğu ve bu hizmetler için ödenen ücretler aşağıda sunulmuştur:

Tablo 11. Zâviye'de Sunulan Hizmetlerin Muhasebe Yılları İtibariyle Detaylandırılması

\begin{tabular}{|l|l|l|l|l|l|l|l|l|l|}
\hline & $\begin{array}{l}\text { Zâviye'de } \\
\text { Sunulan } \\
\text { Hizmet- } \\
\text { lerin } \\
\text { Masrafı }\end{array}$ & $\begin{array}{l}\mathbf{1 2 7 2 /} \\
\mathbf{1 8 5 5}\end{array}$ & $\begin{array}{l}\mathbf{1 2 7 5 /} \\
\mathbf{1 8 5 8 -} \\
\mathbf{1 8 5 9}\end{array}$ & $\begin{array}{l}\mathbf{1 2 7 6 /} \\
\mathbf{1 8 5 9 -} \\
\mathbf{1 8 6 0}\end{array}$ & $\begin{array}{l}\mathbf{1 2 8 8} / \\
\mathbf{1 8 7 1 -}\end{array}$ & $\begin{array}{l}\mathbf{1 2 9 3} / \\
\mathbf{1 8 7 6}\end{array}$ & $\begin{array}{l}\mathbf{1 2 9 5} / \\
\mathbf{1 8 7 8}\end{array}$ & $\begin{array}{l}\mathbf{1 3 1 6} / \\
\mathbf{1 8 9 8}- \\
\mathbf{1 8 9 9}\end{array}$ & $\begin{array}{l}\mathbf{1 3 1 7 /} \\
\mathbf{1 8 9 9 -} \\
\mathbf{1 9 0 0}\end{array}$ \\
\hline 1 & $\begin{array}{l}\text { Mevlüt } \\
\text { Yemeği }\end{array}$ & 290 & 490 & 500 & 529,5 & 887 & 639 & 1675 & 1.690 \\
\hline 2 & $\begin{array}{l}\text { Ekmek } \\
\text { dağıtımı }\end{array}$ & $5.613,19$ & 7.700 & 11.100 & 10.690 & 11.200 & $8.250,05$ & $21.055,2$ & $20.825,20$ \\
\hline
\end{tabular}




\begin{tabular}{|c|c|c|c|c|c|c|c|c|c|}
\hline 3 & $\begin{array}{l}\text { Ramazan- } \\
\text { Bayramı } \\
\text { Yemeği }\end{array}$ & 305 & 495,30 & 503 & 1.168 & $1.701,20$ & 1.585 & 2.715 & 2.715 \\
\hline 4 & $\begin{array}{l}\text { Kurban } \\
\text { Bayramı } \\
\text { Yemeği }\end{array}$ & 324 & 520 & 540 & 1.221 & 1.735 & 1.583 & 2.620 & 2.520 \\
\hline 5 & $\begin{array}{l}\text { K1şlık } \\
\text { (elbise, } \\
\text { ayakkab1, } \\
\text { kömür) } \\
\text { masrafı }\end{array}$ & 505 & 500 & 600 & 1.600 & 2.500 & 3.000 & 3.431 & 1.271 \\
\hline 7 & $\begin{array}{l}\text { Mücâvir, } \\
\text { fakir ve } \\
\text { misa- } \\
\text { firlerin } \\
\text { yemek- } \\
\text { masrafi }\end{array}$ & $3.742,20$ & 1.638 & 1.140 & 3.776 & 5.191 & 5.200 & - & $3.742,20$ \\
\hline 8 & $\begin{array}{l}\text { Zâviyede } \\
\text { vefat } \\
\text { edenlerin } \\
\text { kefen/ } \\
\text { defin } \\
\text { masrafi }\end{array}$ & - & 100 & 470 & - & $1.343,30$ & 1.337 & 1.735 & 1.551 \\
\hline 9 & $\begin{array}{l}\text { ‘Ayn-1 } \\
\text { Kârim } \\
\text { köyü } \\
\text { şeyhleri } \\
\text { yemeği }\end{array}$ & 60 & - & - & & - & - & - & - \\
\hline 10 & $\begin{array}{l}\text { Masrûf } \\
\text { 'alâ aciz } \\
\text { ve du'afâ } \\
\text { ve eytâm } \\
\text { ve erâmil } \\
\text { bi'z-zâ- } \\
\text { viye } \\
\text { ve'l-harra } \\
\text { ve'r-Rev- } \\
\text { vâk mi- } \\
\text { ne'l-Me- } \\
\text { ğâribe }\end{array}$ & - & - & - & - & - & - & 1.720 & 1.950 \\
\hline 11 & $\begin{array}{l}\text { Meğâ- } \\
\text { ribe'ye } \\
\text { tesfîrat } \\
\text { (yol mas- } \\
\text { rafları) }\end{array}$ & - & - & - & - & - & - & 10.143 & 9.871 \\
\hline \multicolumn{2}{|r|}{ Toplam } & $10.839,39$ & $10.943,3$ & 14.853 & 19.277 & $24.557,5$ & $21.594,05$ & $45.094,2$ & $46.135,4$ \\
\hline
\end{tabular}


Tablo 11'de sunulan veriler incelendiğinde; ilk dikkati çeken husus zâviyede sunulan hayır hizmetlerinin yıllar itibariyle hem sayıca hem de harcanan miktar bakımından artmasıdır. Örneğin 1272/1855-56 tarihli Muhasebe Kaydı'nda vakfin hayır hizmetleri toplamda 8 kalemde 11.060 kuruş 44 para olmuşken, bu miktar çalışma çerçevesinde incelen son iki muhasebe kaydından ilkinde 11'e; ikincisinde ise 12 kaleme ve ilkinde 45.003 kuruş 2 paraya, sonuncusunda ise 47.874 kuruş 4 paraya ulaşmıştır.

Öte yandan, vakıf muhasebe kayıtlarına eklenen ve önceki muhasebelerde yer almayan iki kalemden ilkinde "Masrûf 'alâ 'ucĥz ve du'afâ ve eytâm ve erâmil bi'z-zâviye ve'l-harra ve'r-Revvâk mine'l-Meğâribe" başlı̆̆ altında mahallede bulunan aciz, zayıf, yetim ve dullara yardım amacıyla ödemeler yapılmıştır. İkincisinde ise, Kudüs’ten Mağrib'e dönecek olan Mağribliler'e ödenen yol giderleri yer almıştır. Bu da yine miktar bakımından önemli gider kalemleri olarak kaydedilmiştir. Her iki durumun da vakfın artan gelirleri ile dönemin sosyal ve ekonomik şartları ile ilgili olduğu açıktır. Bu konulara ilişkin görüşlere çalışmanın değerlendirme kısmında yer verilecektir.

\section{Tamir ve Bakım Giderleri}

Ebu Medyen el-Ğavs'in torunu Şuayb bin Muhammed bin el-Şuayb tarafindan kurulan vakfin H. 29 Ramazan 720/ M. 2 Kasım 1320 tarihli vakfiyesinde ayrica; “... ve bu vakfin ta'mîr ve islâh ve salâhı ve termîm ve aynının bekâsı ve rey've gallâtının tezyîd ve tenmiyesi ile başlamak ve mezbûr karyeyi ['Ayn-ı Kârim] müştemilâtı ile beraber iki seneden ziyâde müddetle îcâr itmemek ve akdi evvel bitmeden akd-i sânîyi yapmamak bu vakfin cümle mütevellîleri üzerine vâcib ve lâzımdır..." denilmek sûretiyle vakfın gelirleri ile öncelikle vakfin tamir ve bakımının yapılması, vakıf gelirlerinin artırılması ve vakıf akarlarının iki yıldan fazla kiraya verilmemesi ve ilk kira sözleşmesinin süresi bitmeden de ikinci sözleşmenin yapılmaması vakıf mütevellilerine şart kı1ınmıştır. ${ }^{32}$

Vakıfların kuruluşlarının hukuki belgeleri olan vakfiyelerde çoğu zaman, öncelikle kurulan hayır müesseselerinin ve akarlarının, gelirlerden düzenli olarak ayrılan paralarla veya gelir fazlası ile ihtiyaçları halinde, bakım ve onarımlarının yapılması şart koşulurdu. ${ }^{33}$ Vakfiyelerde böyle bir şart yer almasa bile, vakfin temel amacının sonsuza kadar hizmet verebilmesi olduğu için vakıf yöneticisi olan

32 VGMA, Defter No 583: Sayfa No 27/ Sira No 20.

33 Fuat Köprülü, "Vakıf Müessesesi ve Vakıf Vesikalarının Tarihi Ehemmiyeti”, Vakıflar Dergisi, 1, 1938, s. 1-6; Bahaeddin Yediyıldız, "Vakıf" Maddesi, MEBİslam Ansiklopedisi, cilt 13, 1986, s. 153; Mehmet Genç, "Klasik Osmanlı Sosyal-İktisadi Sistemi ve Vakıflar", Vakıflar Dergisi, say1 42, 2014, s. 9-18. 
mütevelli, gerekli olduğu durumlarda onarıma muhtaç bina veya mekânları tamir ettirmeye yetkili idi. Zira bir mütevellinin öncelikli görevi vakıf akar ve hayratlarının bakım ve onarımını en güzel şekilde yaptırmaktı. Vakıf gelirlerinin harcanmasında öncelik vakfa ait akar ve hayrâtların bakım ve onarımına verilirdi. Bu iş için gerekli harcamaların yapılması mütevellinin yetkisi dâhilinde idi. Mütevelli, tamir için yeterli para bulunmaması durumunda, mürtezikaya maaşlarını vermeme hakkına bile sahipti. Hatta o, vakıf akar ve hayrâtının onarımına harcanmak kaydıyla vakıf adına borçlanabilmekte idi. ${ }^{34}$

Tablo 12. Musakkafât Nev'inden Vakıf Mülklerin

Tamir ve Bakımları (Kuruş/Para)

\begin{tabular}{|c|c|c|c|c|c|c|c|c|c|c|}
\hline No & $\begin{array}{c}\text { Muhasebe } \\
\text { Yılı }\end{array}$ & Ev & Dükkân & Diğer & Gazze & Zâviye & $\begin{array}{c}\text { Toplam- } \\
\text { Harcama } \\
\text { Kalemi }\end{array}$ & $\begin{array}{c}\text { Toplam } \\
\text { Tamir } \\
\text { Masraf- } \\
\text { ları }\end{array}$ & $\begin{array}{c}\text { Toplam } \\
\text { Gider }\end{array}$ & \% \\
\hline $\mathbf{1}$ & $\begin{array}{c}1272 / \\
1855-1856\end{array}$ & - & - & - & - & 1 & $\mathbf{1}$ & $4.061,5$ & $16.023,17$ & $\mathbf{2 5 , 3 5}$ \\
\hline $\mathbf{2}$ & $\begin{array}{c}1275 / \\
1858-1859\end{array}$ & - & - & - & - & 2 & $\mathbf{2}$ & 8.210 & $27.614,20$ & $\mathbf{2 9 , 7 3}$ \\
\hline $\mathbf{3}$ & $\begin{array}{c}1276 / \\
1859-1860\end{array}$ & - & - & 2 & - & 5 & $\mathbf{7}$ & 2.299 & 25.796 & $\mathbf{8 , 9 1}$ \\
\hline $\mathbf{4}$ & $\begin{array}{c}1288 / \\
1871-1872\end{array}$ & 9 & 1 & 1 & 1 & 2 & $\mathbf{1 4}$ & $10.187,5$ & $32.040,05$ & $\mathbf{3 1 , 8 0}$ \\
\hline $\mathbf{5}$ & $1293 / 1876$ & 13 & 2 & 4 & 1 & 4 & $\mathbf{2 4}$ & $31.449,20$ & $57.893,10$ & $\mathbf{5 4 , 3 2}$ \\
\hline $\mathbf{6}$ & $1295 / 1878$ & 12 & - & 5 & - & 2 & $\mathbf{1 9}$ & 19.171 & $43.754,25$ & $\mathbf{4 3 , 8 1}$ \\
\hline $\mathbf{7}$ & $\begin{array}{c}1316 / \\
1898-1899\end{array}$ & 22 & 3 & 3 & - & 5 & $\mathbf{3 2}$ & $7.771,2$ & $60.542,22$ & $\mathbf{1 2 , 8 3}$ \\
\hline $\mathbf{8}$ & $\begin{array}{c}1317 / \\
1899-1900\end{array}$ & 18 & 1 & 4 & - & 4 & $\mathbf{2 7}$ & $3.726,25$ & $81.306,20$ & $\mathbf{4 , 5 8}$ \\
\hline \\
\hline
\end{tabular}

Tablo 12'de yer alan verilere ilişkin detaylı bilgi verecek olursak; 1272/185556 yılı ile 1275 1858-59 yılına ait muhasebe kayıtlarında "Vakf-ı şerifin müsakkafâtının tamiri masrafi" başlığı altında tek kalemde tamir masrafları yazılmıştır. Dolayısıyla bu iki yılda tamir ve bakımı yapılan vakıf musakkafâtına ilişkin bilgi sahibi değiliz. Bunun yanı sıra, yine benzer şekilde 1276/1859-60 tarihli muhasebe kaydında da yine tek kalemde kaydedilmiş ancak buna ilaveten vakıf değirme-

34 Bahaeddin Yediyıldız, "Müessese-Toplum Münasebetleri Çerçevesinde XVIII. Asır Türk Toplumu ve Vakıf Müessesesi”, Vakıflar Dergisi, sayı 15, 1982, s. 23-53. 
ninde yapılan 1.444 kuruş tutarındaki tamir masrafı ayrı bir şekilde not edilmiştir. Dolayısıyla da vakfa ait tamir giderleri iki kalemde kaydedilmiştir. Diğer kayıtlarda ise, tamir ve bakımı yapılan vakıf musakkafâtı etraflıca tavsif edilmiştir.

Tablo 12'de yer alan bilgiler değerlendirildiğinde; tamir ve bakım masraflarının toplu bir şekilde kaydediliği 1272/ 1855-1856, 1275/ 1858-1859, 1276/ 1859-1860 yıllarına ait muhasebe kayıtları haricinde, en fazla vakıf evlerinin tamir edilerek, bakımlarının yapıldığı görülmüştür. Bunu "diğer" başlığı altında örneğin 1295/1878 tarihli muhasebe kaydında beş kalemde; Meğaribe Mahallesi'nde bulunan değirmenin duvarının tamiri (20 kuruş), Meğaribe Mahallesi'nde bulunan kuyunun duvarının boyanması (110 kuruş), Dellâlîn Çarşısı'nda bulunan köprünün biniş yerinin yıkım masrafı (217 kuruş, 20 para), Meğâribe Mahallesi’nde bulunan sebze bahçesinin duvarının yapımı (1.920 kuruş) ve son olarak da Meğaribe Mahallesi'nde yer alan değirmen ve firının yüzeyinin boyanması (1725 kuruş) olarak kaydedilmiştir.

1288/ 1871-1872 ve 1293/ 1876-1877 tarihli muhasebe kayıtlarından ilkinde “Gazze'de bulunan Ebu Medyen el-Ğavs Zâviyesi'nin tamiri ve diğer çatılı mülklerin termîmleri” ve ikincisinde de "Gazze'de bulunan Ebi Medyen el-Ğavs Zâviyesi çalışanlarının ücretleri ve musakkafâtın termîmi" başlıkları altında tamir masrafları 400 ve 465 kuruş olarak tek kalemde toplu bir şekilde kaydedilmiştir.

Öte yandan, vakıf musakkafâtına ilişkin yapılan tamir ve bakımlara ilişkin detaylı bilgi verecek olursak, vakfin 1288/1871-72 cari y1lı muhasebe kaydında tamir ve bakıma ilişkin detaylar şöyle kaydedilmiştir:

Tablo 13. 1288/1871-72 Yılı Vakıf Musakkafâtına Yapılan Tamir/Bakım Masrafları

\begin{tabular}{|l|l|r|}
\hline No & Tamir/Bakım Yapılan Musakkafâta İlişkin Detaylar & Masraflar \\
\hline 1 & $\begin{array}{l}\text { Vakfın musakkafâtının kapılarının termîmi ve çatılı yapıların } \\
\text { onarımı müddet-i li-sene }\end{array}$ & $2.393,5$ \\
\hline 2 & $\begin{array}{l}\text { Dellâllar Çarşısı'nda bulunan iki evin çatı yüzeyi, üstü ve } \\
\text { damın sıvanması }\end{array}$ & 1.500 \\
\hline 3 & $\begin{array}{l}\text { Tabûne Merdiveni’nde bulunan evin termimi, evin içerisinde } \\
\text { bulunan odaların ve dışında bulunan yerlerin tekmili }\end{array}$ & 300 \\
\hline 4 & $\begin{array}{l}\text { Hammâre'nin evine küçük mutfak inşa edilmesi, küçük bir } \\
\text { oda açılması, bazı termimatlar }\end{array}$ & 400 \\
\hline 5 & $\begin{array}{l}\text { Meğaribe Mahallesi’nde bulunan Sıyam evinin tamiri, kapı- } \\
\text { ların onarım ve beyaza boyanması }\end{array}$ & \\
\hline
\end{tabular}




\begin{tabular}{|c|c|c|}
\hline 6 & $\begin{array}{l}\text { Ermeni Mahallesi’nde bulunan evin onarımı, } 3 \text { ev için } 3 \\
\text { tabaka (kat) açılması ve diğer gerekli onarımlar }\end{array}$ & 500 \\
\hline 7 & $\begin{array}{l}\text { Yahudi Mahallesi'nde bulunan 'Umya evinin yeni tabaka- } \\
\text { sında yüzeyin taş/mermer/karo ile döşenmesi }\end{array}$ & 1500 \\
\hline 8 & Dellalin Çarşısı'nda bulunan dükkânın tamiri & 130 \\
\hline 9 & $\begin{array}{l}\text { Nasara Mahallesi'nde bulunan ve evlad-1 Şeyh Yusuf Efendi } \\
\text { el-Âlemi ve ortağı tarafından tasarruf edilen evin tamiri }\end{array}$ & 380 \\
\hline 10 & $\begin{array}{l}\text { Bâb-1 Hutta Mahallesi’nde bulunan evin tamir, boyama ve } \\
\text { diğger masrafları }\end{array}$ & 1.200 \\
\hline 11 & $\begin{array}{l}\text { Meğaribe Mahallesi’nde Ümmü Nida, İbrahim Gülsüm, } \\
\text { Süleyman as-Sâkıt, Şeyhü'l-Hârre’ye ait olan evlerin astar- } \\
\text { larının kaldırılması, temizlenmesi ve yüzeylerinin onarım } \\
\text { giderleri }\end{array}$ & 964 \\
\hline 12 & $\begin{array}{l}\text { Gazze'de bulunan Ebu Medyen el-Ğavs Zaviyesi'nin tamiri } \\
\text { ile diğer çatılı mülklerin termîmleri }\end{array}$ & 400 \\
\hline Toplam & & $10.187,5$ \\
\hline
\end{tabular}

Buna göre; vakıf musakkafâtından en fazla evlerin tamir ve bakımları yapılmıştır. Yalnızca bir kalemde bir dükkânın tamir masrafı kaydedilmişken, bir kalemde de toplu bir şekilde tek kalemde 2.393 kuruş 5 para olarak vakıf musakkafâtının kapılarının tamiri ve çatılarının onarımı kaydedilmiştir. Cari yılda en fazla tamir ve bakım masrafını da bu kalem oluşturmuştur. Son olarak, Gazze'de bulunan vakıf musakkafâtının tamir masrafi da 400 kuruş olarak, detay belirtmeden tek kalemde yazılmıştır.

1316/1888-89 tarihli muhasebe kaydı, incelenen muhasebe kayıtları arasında en fazla tamir ve bakıma bütçe ayrılan yıl olması bakımından çalışmanın bu kısmında yer verilen giderlerin detayları şöyledir:

Tablo 14. 1316/1888-89 tarihli muhasebe kaydı Tamir ve Bakım Giderleri

\begin{tabular}{|l|l|r|}
\hline No & Tamir/Bakım Yapılan Musakkafâta İlişkin Detaylar & Masraflar \\
\hline 1 & $\begin{array}{l}\text { Rum Kilisesi tarafından kiralanan Haddadin } \\
\text { Mahallesi'ndeki evin tamiri }\end{array}$ & 889 \\
\hline 2 & $\begin{array}{l}\text { El-Hac Abdullah el-Varğami el-Mağribi’nin oturduğu } \\
\text { Meğaribe Mahallesi’ndeki evin tamiri }\end{array}$ \\
\hline
\end{tabular}




\begin{tabular}{|c|c|c|}
\hline 3 & $\begin{array}{l}\text { İbrahim Hamis'in oturduğu Meğaribe Mahallesi'ndeki evin } \\
\text { tamiri }\end{array}$ & 265 \\
\hline 4 & $\begin{array}{l}\text { Meğaribe Mahallesi'nde bulunan zaviyenin odasının tamiri } \\
\text { ve kassarasının termimi }\end{array}$ & 1750 \\
\hline 5 & $\begin{array}{l}\text { El-Hac Hamid Tutah ve Selim el-Haraizin otruduğu iki } \\
\text { dükkanın tamiri }\end{array}$ & 131 \\
\hline 6 & $\begin{array}{l}\text { Ermeni Mahallesi'nde Zeheb es-Siknaci tarafindan oturulan } \\
\text { evin tamiri }\end{array}$ & 496 \\
\hline 7 & $\begin{array}{l}\text { Meğaribe Mahallesi’nde Reşid Ebu Mes'ud tarafindan } \\
\text { oturulan evin tamiri }\end{array}$ & 325 \\
\hline 8 & $\begin{array}{l}\text { Meğaribe Mahallesi’nde Ağrabi Halil tarafindan oturulan } \\
\text { evin tamiri }\end{array}$ & 254,20 \\
\hline 9 & $\begin{array}{l}\text { Meğaribe Mahallesi'nde Selim el-Ramlevî tarafindan } \\
\text { oturulan evin ahşap ... }\end{array}$ & 22,20 \\
\hline 10 & $\begin{array}{l}\text { Meğaribe Mahallesi'nde Abdullah 'Urfe tarafindan oturulan } \\
\text { evin termimi }\end{array}$ & 194 \\
\hline 11 & $\begin{array}{l}\text { Yahudi Mahallesi'nde Siknaci tarafindan oturulan ve } \\
\text { Himâre evi olarak bilinen evin tamiratı }\end{array}$ & 496,20 \\
\hline 12 & $\begin{array}{l}\text { Yahudi Mahallesi'nde bulunan ve Relif es-Siknaci } \\
\text { tarafindan oturulan evin tamiri }\end{array}$ & 376,20 \\
\hline 13 & $\begin{array}{l}\text { Meğaribe Mahallesi'nde Abdulcevad el-Halili tarafindan } \\
\text { oturulan evin tamiri }\end{array}$ & 211,20 \\
\hline 14 & $\begin{array}{l}\text { Dellallar Çarşısı'nda bulunan ve Siknaci tarfindan oturulan } \\
\text { evin tamiri }\end{array}$ & 500 \\
\hline 15 & $\begin{array}{l}\text { Bâb-1 Silsile’de Yahudi Siknaci tarafından oturulan } \\
\text { dükkanın termimi }\end{array}$ & 51 \\
\hline 16 & Afğânî tarafından oturulan kahve yakınındaki evin tamiri & 411 \\
\hline 17 & $\begin{array}{l}\text { Meğaribe Mahallesi'nde bulunan ve eş-Şeyh Abdulkadir } \\
\text { el-Mağribi tarafından oturulan evin termimi }\end{array}$ & 86 \\
\hline 18 & $\begin{array}{l}\text { Meğaribe Mahallesi’nde bulunan ve Ömer Alvan tarafindan } \\
\text { oturulan evin termimi ve tamiri }\end{array}$ & 164 \\
\hline 19 & $\begin{array}{l}\text { Meğaribe Mahallesi’nde bulunan ve Ivaz tarafindan } \\
\text { oturulan evin termimi }\end{array}$ & 47,20 \\
\hline
\end{tabular}




\begin{tabular}{|l|l|r|}
\hline 20 & $\begin{array}{l}\text { Meğaribe Mahallesi’nde bulunan hakurenin merdiveninin } \\
\text { 1slah edilmesi, tamiri ve duvarının termimi }\end{array}$ & 35,20 \\
\hline 21 & El-Hac İsmail tarfından oturulan evin boyanması & 21 \\
\hline 22 & İbn-i Bâruh tarafından oturulan evin tamiri & 295 \\
\hline 23 & Bahse konu evde bulunan odanın, eyvanın tamir ve termimi & 195 \\
\hline 24 & Söz konusu evin duvarının termimi & 186 \\
\hline 25 & Ahurun ahşap kapısının tamiri & 9,20 \\
\hline 26 & $\begin{array}{l}\text { Meğaribe Mahallesi’nde bulunan ve Derviş Ahyâm } \\
\text { tarafindan oturulan evin termimi }\end{array}$ \\
\hline 27 & Meğaribe Mahallesi’nde bulunan değirmenin termimi & $\mathbf{7 4 , 2 0}$ \\
\hline 28 & $\begin{array}{l}\text { Meğaribe Mahallesi’nde bulunan ve et-Tavânî tarafından } \\
\text { oturulan evin ahşap kapısının termimi }\end{array}$ & 49,20 \\
\hline Toplam & & $\mathbf{7 . 7 7 1 , 2 0}$ \\
\hline
\end{tabular}

Tablo 14’te görüleceği gibi, vakıf 1316/1898-99 cari yılında vakıf, toplam 28 kalemde tamir ve çeşitli bakımlar yapmıştır. Tablo 12 ile kıyaslandığında bu sayı iki katından biraz fazladır. Tamir ve bakımların tamamına yakını vakıf evlere yapılmıştır. Evlerin yanı sıra, en fazla harcama yapılan tamir ve bakım kalemini 1.750 kuruş ile Meğâribe Mahallesi'nde bulunan zâviye oluşturmuştur. Az sayıda da olsa örneğin, üç dükkan, bir hakûre, bir değirmen ve bir ahır tamiri de yine muhasebe kaydında yer alan diğer tamir ve bakıma ilişkin harcama kalemleri olarak kaydedilmiştir.

Çoğunlukla Meğâribe Mahallesi'nde bulunan evler tamir ve bakıma ihtiyaç duymuştur. Haddâdîn, Yahudi, Ermeni, Dellâllar Çarşısı ve Bâb-1 Silsile mahallesi tamiri yapılan vakıf evlerin bulunduğu diğer mahaller olarak kaydedilmiştir. Evlerin yıllar itibariyle tamire ve bakıma çokça ihtiyaç duymalarında Kudüs'teki ev tiplerinin ve yapısının belirleyici olduğu açıktır. Şöyle ki; evlerin çoğu taştan inşa edilmekteydi, içleri sıvalıydı. Büyük evlerde çatılar taş kubbeler şeklinde yapılırken, daha küçük olanlarda birkaç ahşap kirişe yaslanan düz çatılar inşa edilirdi. Evlerin çoğunda çatıya alçak bir korkuluk yapılırdı; burada eşyalar saklanır, çalış1ır ve yazın kimi zaman uyumak için kullanılırdı. ${ }^{35}$

35 Dror Ze'evi, Kudüs:17. Yüzyılda Bir Osmanlı Sancağında Toplum ve Ekonomi, çev. S. Çağlayan, İstanbul, Tarih Vakfı Yurt Yayınları, 2000, s. 34. 


\section{Görevli Ücretleri}

Tablo 9'da görüleceği üzere toplamda vakıftan sürekli olarak maaş alan vakıf görevlileri mütevelli, kâtib ve câbî olarak kaydedilmiştir. " 'An zâbıtânı vakf" olarak da adlandırılabilecek bu görevliler vakfın yönetiminden sorumlu görevlilerdir. Görevlilerin ücret dağılımlarının yıllara göre dağılımları ise şöyledir:

Tablo 15. Vakıf Personel Sayıları ve Ücretleri (Kuruş/Para)

\begin{tabular}{|c|c|c|c|c|c|c|c|c|c|}
\hline & Görevli Adı & $\begin{array}{l}1272 / \\
1855- \\
1856\end{array}$ & $\begin{array}{l}1275 / \\
1858- \\
1859\end{array}$ & $\begin{array}{l}1276 / \\
1859- \\
1860\end{array}$ & $\begin{array}{l}1288 / \\
1871- \\
1872\end{array}$ & $\begin{array}{l}1293 / \\
1876\end{array}$ & $\begin{array}{l}1295 / \\
1878\end{array}$ & $\begin{array}{l}1316 / \\
1898- \\
1899\end{array}$ & $\begin{array}{l}1317 / \\
1899- \\
1900\end{array}$ \\
\hline 1 & Mütevelli & 200 & - & - & 200 & 200 & 200 & 200 & 200 \\
\hline 2 & Kâtib & 200 & 200 & 200 & 200 & 200 & 200 & 200 & 200 \\
\hline 3 & Câbî/Nakîb & 180 & 200 & 200 & 180 & 180 & 180 & 180 & 180 \\
\hline 4 & $\begin{array}{l}\text { Sahratullah-1 } \\
\text { Müşerrefe'de } \\
\text { Receb, Şaban } \\
\text { ve Ramazan } \\
\text { aylarında kârî̀- } i \\
\text { rubâ'(rubâa '̂̀ } \\
\text { okuyan) } \\
\text { Mağribiler'in } \\
\text { ücreti }\end{array}$ & - & - & - & 500 & 500 & 500 & - & 997,10 \\
\hline \multicolumn{2}{|c|}{ Toplam } & 580 & 400 & 400 & 1.080 & 1.080 & 1.080 & 580 & $1.577,1$ \\
\hline
\end{tabular}

Vakıf giderleri arasında oldukça cüz'i bir orana sahip vakıf görevlilerinin maaşları zamanla pek fazla bir değişime uğramamıştır. Öte yandan, vakıf giderleri arasına 1288/1871-1872 y1lından itibaren "Sahratullah-ı Müşerrefe'de Receb, Şaban ve Ramazan aylarında rubâ‘î okuyan Mağribilerin ücreti” dâhil olmuştur. Y1llık 500 kuruş ödenen bu görevi kaç kişinin icra ettiği belirtilmemekle birlikte, 1317/1899-1900 yılında bu miktar 997 kuruş 10 paraya yükselmiştir. Tablo 15'te yer alan görevli ücretlerinden ayrı olarak 1293/1876 tarihli muhasebe kaydında giderler arasında bir kalemde "Zâviye çalışanlarının ücretleri ve zâviyede vefat edenlerin kefen ve defin masrafları" başlığ altında 1.343 kuruş 30 para kaydedilmiştir. Ancak bu kalemde zâviye çalışanlarının kimler olduğu, ne kadar ücret aldıkları net bir şekilde belirtilmediği için bu kalem vakıf tarafından sunulan hayır hizmetleri bağlamında değerlendirilmiştir. 


\section{Diğer Masraflar}

Çalışma çerçevesinde incelenen muhasebe kayıtlarının gider kalemleri arasında kaydedilen ve tek bir başlık altında sınıflandırılamayan çeşitli gider kalemleri bulunmaktadır. Bunlar arasında zâviyenin aydınlatma masrafları ile içeriği belirtilmeyen çeşitli harcamalar kaydedilmiştir. Zâviye'de kullanılan hasır, sergi, ibrik, süpürge, kova ve kandil gibi araç ve gereçler de yine zâviyenin gider kalemleri arasında şöyle kaydedilmiştir:

Tablo 16. Vakıf zâviyenin masrafları

\begin{tabular}{|c|c|c|c|c|c|c|c|c|c|}
\hline No & $\begin{array}{l}\text { Zâviye'de } \\
\text { Yapılan Tamir/ } \\
\text { Bakım Masrafı }\end{array}$ & $\begin{array}{c}1272 / \\
1855- \\
1856\end{array}$ & $\begin{array}{l}1275 / \\
1858- \\
1859\end{array}$ & $\begin{array}{c}1276 / \\
1859- \\
1860\end{array}$ & $\begin{array}{c}1288 / \\
1871- \\
1872\end{array}$ & $\begin{array}{l}1293 / \\
1876\end{array}$ & $\begin{array}{l}1295 / \\
1878\end{array}$ & $\begin{array}{c}1316 / \\
1898- \\
1899\end{array}$ & $\begin{array}{l}1317 / \\
1899- \\
1900\end{array}$ \\
\hline 1 & $\begin{array}{l}\text { Aydınlatma } \\
\text { Masrafi }\end{array}$ & 201,5 & 242 & 360 & 292,5 & 220 & 381,20 & 900 & 780 \\
\hline 2 & $\begin{array}{l}\text { Masârif-i } \\
\text { mesâlih-i zâviye } \\
\text { fî̀ müddet-i li } \\
\text { sene }\end{array}$ & & 0 & 500 & 1108,5 & - & 400 & 1.670 & 322,2 \\
\hline 3 & $\begin{array}{l}\text { Zaviye için } \\
\text { hasır/sergi } \\
\text { masrafi }\end{array}$ & - & 0 & 100 & - & 100 & - & 395 & 627 \\
\hline 4 & $\begin{array}{l}\text { Zaviye için } \\
\text { ebârik masrafı }\end{array}$ & - & 0 & 42 & - & 500 & - & 65 & - \\
\hline 5 & $\begin{array}{l}\text { Zaviye için } \\
\text { süpürge/kandil/ } \\
\text { kova masrafı }\end{array}$ & - & 30 & 45 & - & 45 & - & 375 & 332 \\
\hline \multicolumn{2}{|c|}{ Toplam } & 201,5 & 272 & 1.047 & 1.401 & 415 & 781,2 & 3.405 & $2.061,2$ \\
\hline
\end{tabular}

Vakıf zâviye için alınan çeşitli gider kalemlerinin yanı sıra yıllara göre farkl11ık arz eden bazı diğer giderlerden 1272/1855-1856 y1lı muhasebe kaydında örneğin üç kalemde kaydedilmiş ve toplamda 350 kuruş başkaca gider kalemleri de mevcuttur. Vakfın önceki yıldan devreden borcu (130 kuruş) ile muhasebe harç giderleri (200 kuruş) bu gider kalemleridir. Vakfa ait dükkânın hikr bedeli olarak da 20 kuruş kaydedilmiştir. Öte yandan, 1275/1858-1859 ve 1276/18591860 yıllarına ait diğer masraflara bakılacak olursa, detayları şöyledir: 
Tablo 17. 1275/1858-1859 ve 1276/1859-1860 y1llar1 gider kalemleri arasında diğer masraflar

\begin{tabular}{|l|l|l|r|}
\hline No & Diğer Masraflar & Yılları & Miktarı \\
\hline 1 & Kiralamalar için gerekli evrakların ücreti & 1275 & 135 \\
\cline { 3 - 4 } & & 1276 & 150 \\
\hline 2 & Vakfa ait iki dükkânın hikr bedeli & 1275 & 27 \\
\cline { 3 - 4 } & & 1276 & 27 \\
\hline 3 & Vakıf için yeni bir tabaka inşasının masrafları & 1275 & 0000 \\
\cline { 3 - 4 } & & 1276 & 3.000 \\
\hline 4 & Vakfa tabi dükkânın hikr masrafı & 1275 & 000 \\
\cline { 3 - 4 } & & 1276 & 150 \\
\hline 5 & Vakfın 274 yılı sonundan kalan borcu & 1275 & 40 \\
\cline { 3 - 4 } & & 1276 & 20 \\
\hline 6 & Es-Seyyid Mehmed Efendi aylık masrafi & 1275 & 19 \\
\cline { 3 - 4 } & & 1276 & $\mathbf{1 2 7 5}$ \\
\hline Toplam & $\mathbf{1 2 7 6}$ & $\mathbf{3 . 3 6 6}$ \\
\hline
\end{tabular}

Buna göre; 1275/1858-1859 ve 1276/1859-1860 yılları gider kalemleri arasında diğer masraflar başlığı altında ilk gider kalemi kiralamalar için gerekli evrakların ücreti sonraki kayıtlarda çoğunlukla "semen-i evrâk ve harc-ı senedât-ı kontratu" olarak kaydedilen ve sırası ile 135 ve 150 kuruş olmuştur. Vakfa ait toplamda iki kalemde kaydedilen hikr bedellerinden ilki 27 kuruş, ikincisi ise 1276/1859-1860 yılında 150 kuruş olmuştur. Yalnızca 1276/1859-1860 yılında zâviye için yapılan 42 kuruşlık bir gider kalemini, vakıf için yeni bir kat inşası masrafı olarak 3.000 kuruş takip etmiştir. Vakfın önceki yıllardan kalan borcu 40 ve 20 kuruş ve son olarak da vakfın mütevellisi es-Seyyid Mehmed Efendi'nin her iki yılda da değişmeyen 19 kuruşluk gider kalemi olarak kaydedilmiştir. Önceki yıllara göre daha fazla gider kaleminin olduğu 1276/1859-1860 yılında vakıf için yeni bir kat inşası bu giderler arasında en masraflı olan gider kalemi olmuştur.

1288/ 1871-1872 tarihli muhasebe kaydında ise; yalnızca iki kalemde diğer masraflar başlığ altında kategori edilebilecek giderler yazılmıştır. Bunlardan ilkinde; vakfın önceki yıllara göre miktarı artmayan cari yıldaki musakkafâtının hikr bedelleri olarak 26 kuruş kaydedilmişken, ikincisinde "semen-i evrâk ve harc-ı senedât-ı kontratu" başlığı altında evrak bedeli ve kontratu senetlerinin 
vergileri olarak 352 kuruş 05 para kaydedilmiştir. Bu gider kaleminin önceki yıllara göre iki kattan daha fazla bir artış göstermiştir. Bu da yeni kiraya verilen ya da yenilenen kira sözleşmelerinin sayıca oldukça arttığına işaret etmektedir.

1293/1876 yılına ait muhasebe kaydında gider kalemleri arasında mevcut yılda musakkafâtların hikr giderleri olarak yine 26 kuruş ve Ramle'de bulunan bostanın sene [12] 92 Martından olan arsa vergisi 85 kuruş olarak kaydedilmiştir.

1295/1878 yılına ait muhasebe kaydında gider kalemleri arasında mevcut yılda musakkafâtların hikr giderleri iki kuruş artarak 28 kuruş olmuştur. İkinci olarak da, “'An resm-i i 'lân men'i da 'va 'alâ ba 'zı arâzi fîhi 'Ayn-ı Kârim” başlığ altında ilan vergisi olarak 1.000 kuruş kaydedilmiştir.

Vakfin 1316/ 1898-1899 yılı gider kalemleri arasına diğer masraflar kalemleri sayıca artmıştır. Detayları ise şöyledir:

Tablo 18. 1316/ 1898-1899 y1l gider kalemleri arasında diğer masraflar

\begin{tabular}{|l|l|r|}
\hline No & Diğer Masraflar & Miktarı \\
\hline 1 & “'Arzuhâlât ve ihdâriyât li-mesâlihi'l-vakf” & 291 \\
\hline 2 & $\begin{array}{l}\text { İdare Meclisi’nin kararı ile 'Ayn-1 Kârim köyünün keşif } \\
\text { bedeli }\end{array}$ & 414 \\
\hline 3 & $\begin{array}{l}\text { El-Hac Beşir'in vekâlet ücreti ve dava açılması için vekâlet } \\
\text { masrafları }\end{array}$ & 756 \\
\hline 4 & Cûretu'l-'Inâb'da bulunan arsanın vergisi & 16,10 \\
\hline 5 & Bâbü'l-Meğaribe dışında bulunan sebze bahçesinin vergisi & 16,10 \\
\hline 6 & Silvan'da bulunan arsanın vergisi & 4,30 \\
\hline 7 & $\begin{array}{l}\text { Dellalin Çarşısı'nda bulunan dükkanın hikr gideri, Seyyid } \\
\text { Abbas Efendi el-Câunî ve şirketinin elinde bulunan }\end{array}$ & 16,20 \\
\hline 8 & Lud'dan zeytin masrafı & $\mathbf{7 2}$ \\
\hline 9 & Vakfın önceki yıldan borcu & $\mathbf{2 . 2 5 9 , 8 2}$ \\
\hline Toplam & & 674,12 \\
\hline
\end{tabular}

Buna göre dokuz kalemde kaydedilen gider kalemleri arasında çoğunlukla vergiler ve hikr giderleri yer almıştır. Önceki yıllardan farklı olarak vakfın işleri için yazılan arzuhâl ve ihtarnâme masrafları ve vakıf mütevellisi el-Hac Beşir'in vekâlet ücretleri kaydedilmiştir. Vakfın önceki yıldan borcu da oldukça artmış ve 674 kuruş 12 paraya ulaşmış̧ır. 
Çalışma çerçevesinde incelenen 1317/ 1899-1900 tarihli son muhasebe kaydında gider kalemleri arasında zikredilen masraflar şöyledir:

Tablo 19. 1317/ 1899-1900 yılı gider kalemleri arasında diğer masraflar

\begin{tabular}{|l|l|r|}
\hline No & Diğer Masraflar & Miktarı \\
\hline 1 & $\begin{array}{l}\text { Mal vergisi- Vakfın Kudüs dışında Cûretü'l-'Inâb adlı yerde } \\
\text { bulunan zeytinlik arsanın }\end{array}$ & 16,10 \\
\hline 2 & $\begin{array}{l}\text { Mal vergisi- Bâb-1 Meğaribe dışında bulunan sebze } \\
\text { bahçesinin }\end{array}$ & 16,10 \\
\hline 3 & Mal vergisi- Silvan Köyü'nde bulunan arsanın & 4,30 \\
\hline 4 & $\begin{array}{l}\text { Abbas Efendi el-Câ'ûnî ve ortağının elinde bulunan Dellâllar } \\
\text { Çarşısı'nda bulunan dükkanın hikr bedeli }\end{array}$ & 136 \\
\hline 5 & $\begin{array}{l}\text { Mal vergisi- Ramle'de bulunan bostanın 1314 ve 1315 } \\
\text { yıllarına ait }\end{array}$ & 62 \\
\hline 6 & $\begin{array}{l}\text { İdare Meclisi'nin kararı ile 'Ayn-1 Kârim köyünün öşür } \\
\text { bedelinin keşif bedeli }\end{array}$ & $\mathbf{2 3 4 , 5}$ \\
\hline Toplam & & \\
\hline
\end{tabular}

Tablo 19'da yer alan giderler önceki yıla ait giderlerle en azından ilk dört kalemde benzerlik arzetmektedir. Farklı olarak vakfın Ramle'dce bulunan bostanının vergi giderleri ile 'Ayn-1 Kârim vakıf köyünün öşür bedelinin keşif bedeli kaydedilmiştir.

Sonuç olarak, çalışmanın bu bölümünde diğer masraflar başlı̆̆g altında tasnif edilen vakıf giderlerinin çoğunlukla vakıf musakkafât ya da müstegallâtı ile vakfın kaza idaresinden aldığı diğer hizmetlere ilişkin vergi giderleri olduğu tespit edilmiştir. Vakıf giderleri arasında en düşük orana sahip olduğu 1275/1858-59 yılında bu gider vakıf bütçesi içerisinde yaklaşık \%2,5 bir gider oranına sahip iken, en yüksek orana sahip olduğu 1316/1898-99 yılı muhaseba kaydında \%9,6 arasında değişen bir gider oranına sahiptir. Bu oranlar da, vakfın Osmanlı yönetiminin taşradaki hizmetleri karşılığında ödediği meblağların yıllar içerisinde farkl11ık arz ettiğini göstermiştir.

Öte yandan, 1317/1899-1900 tarihli muhasebe kaydında diğer kayıtlarda olmayan masraf kalemleri arasında Gazze'de bulunan Ebu Medyen el-Ğavs Zâviyesi'nin giderleri “Masârifât el-vakf bi-Kasaba-i Gazze” başlı̆̆ 1 altında şöyle detaylandırılmıştır: 
Tablo 20. Gazze'de Bulunan Vakıf Giderleri

\begin{tabular}{|l|l|r|}
\hline No & “Masârifâtu'l-vakf bi-Kasaba-i Gazze” & Miktarı \\
\hline 1 & Abdest suyu bedeli & $3.283,05$ \\
\hline 2 & Ekmek bedeli & 5.408 \\
\hline 3 & Hasır bedeli & 500 \\
\hline 4 & Zeytinyağı ve gaz bedeli & 763 \\
\hline 5 & İbrik ve kazan bedeli & 413,10 \\
\hline 6 & Vergi & 443,10 \\
\hline 7 & Mahalle yolunun tanzimi & 888,10 \\
\hline 8 & Kâtib maaş1 & 363,20 \\
\hline 9 & Şe‘âl ve kennâs maaş1 & 396,20 \\
\hline 10 & İmam maaş1 & 389,30 \\
\hline 11 & Ta'mirât & $13.657,05$ \\
\hline 12 & Mütevelli ücreti & 224 \\
\hline \multicolumn{2}{|l|}{ Toplam } & $\mathbf{2 6 . 7 2 8 , 0 1}$ \\
\hline
\end{tabular}

Kudüs'te bulunan Ebu Medyen el-Ğavs Vakfı'na bağlı olan Gazze'deki vakfin gider kalemlerinin de benzerlik arz ettiği görülmüştür. Şöyle ki; Tablo 20'de sunulan veriler sınıflandırıldığında Gazze'de vakıftan sunulan hayır hizmetleri, vakıf mülklerin tamir ve bakımı, görevli ücretleri ile vergi kalemleri başlıklar1 husûle gelmektedir. Burada da aynı adlı zâviyede sunulan hayır hizmetleri arasında en fazla gider kalemi 5.408 kuruş ile ekmek dağıtımına ayrılmıştır. Bunu zâviyede abdest almak için abdest suyu temini, 3.283 kuruş 05 para ile takip etmiştir. Zâviyede serilmek için hasır, aydınlatma için zeytinyağı ve gaz ile ibrik ve kazan giderleri de bu bağlamda değerlendirilebilir. Tamir ve bakım kalemleri ise iki başlıkta sunulmuştur. Bunlardan ilki "ta 'mirât" başlığ altında 13.657 kuruş ve 05 para olarak bu cari yıldaki en yüksek meblağ olmuştur. Mahalle yolunun tanzimi de 888 kuruş 10 para bedel olarak kaydedilmiştir. Üçüncü başlıkta ele alınabilecek gider kalemlerinden görevli ücretleri Kudüs'te bulunan zâviyeye göre hem görevler hem de maaşlar bakımından daha fazladır. Şöyle ki; vakfın mütevellisinin maaşı 224 kuruş olurken, kâtib 363 kuruş 20 para olarak yazılmıştır. Kudüs'teki zâviyeden farklı olarak câbî/nakîb bulunmazken, Gazze'deki zâviyede görevliler arasında imam 389 kuruş 30 para; şe 'al (aydınlatma görevlisi) ve kennâs (süpürgeci) 396 kuruş 20 para ücret almışlardır. Muhasebe kaydında yer alan son başlikta ise vergi kalemi 443 kuruş 10 para olarak kaydedilmiştir. 


\section{El-Bâkî (Kalan)}

Ebû Medyen el-Ğavs ve Şeyh Ömer el-Mücerred Vakıfları'na ait muhasebe kayıtlarında giderler bölümü hesapları "el-bâkî" (kalan, bakiyye) hesaplanması ile devam etmiştir. Buna göre,cari döneme ait borçlar "bâkî-i deyn 'ale'l-vak$f$ "(vakfin kalan borcu), gelir fazlaları ise "fazla-i vakf" şeklinde kaydedilmiştir. Tablo 1'de yer verilen bu bilgilere göre vakıf; 1276/1859-1860, 1288/1871$1872,1293 / 1876$ ve 1295/1878 y1llarında gelir fazlası vermiştir. Bunlardan da 1293/1876 y1lında 32.243 kuruş ve 22 para olarak en fazla gelir fazlası sonraki yıla devredilmiştir. Diğer yıllarda ise sonraki yıla borçlu kalınmıştır.

Vakıf gelir ve giderlerinin oldukça tafsilatlı bir şekilde kaydedildiği muhasebe defterlerinde vakfin bâkî hesapları yazılarak, mütevelli mührü ile hesaplar denkleştirilmiştir. ${ }^{36}$ Bahse konu muhasebe kayıtlarında muhasebenin tasdik süreci de detaylı bir şekilde Osmanlı Türkçesi ile anlatılmıştır. Buna göre örneğin 1316/1898-1899 yılına ait muhasebe kaydının sonunda şu kayıtlara yer verilmiştir:

"Hicrî [1]316 yllına ait Ebû Medyen el-Ğavs ve eş-Şeyh Ömer el-Mücerred Vakfi'nın gelirleri 59.760 kuruş, giderleri ise 60.542 kuruş ve 22 para olup, vakfin borcu 816 kuruş 22 paradır. Bu meblăg deftere kaydedilerek, takdîm edilmiştir.

Fî 1 Muharrem sene [1]321.

Vakf-ı müşârun ileyhin işbu muhasebesi bi'l-mutâla 'a ru'yet olunan diğer muhasebâtına muvâfik ve evrâk-ı müsbitesine mutâbık olduğu anlaşılmış olmağla 'ala'-l-usûl tasdîki husûsu Meclis-i İdâre-i Livâ'ya havale buyurulması bâbinda fermân.

Fî 28 Haziran sene [1]319.

Kudüs-i Şerîf Evkâf Muhasebecisi.

Numro 417. Meclis'e 28 Haziran sene [1]319.

530

[1]316 Sene-i Hicriyesine mahsûben Seyyidinâ eş-Şeyh Ömer elMücerred ve Seyyidinâ Ebî Medyen el-Ğavs -kuddise sirruhu'l-azîzHazretlerinin Evkâf-ı Şerifelerinin vâridât ve masârıfâtını mutasarrıf Evkâfmuhasebece bi 't-tedkîk tasdîk olunan işbu defter 'alel'l-usûl tasdîk kilındı. Fî 5 Temmuz sene [1]319.

Mûcebince." 
Buna göre; bu ve diğer belgelerde vakfın muhasebesinin öncelikle mütevellisi tarafından Kudüs Evkâf Muhasebecisi'ne sunulduğu, sonrasında yapılan kontroller neticesinde tasdîk edilmek üzere Livâ İdare Meclisi'ne gönderildiği anlaşılmaktadır. Livâ İdare Meclisi'nce de incelenen defter uygun görüldügüü takdirde tasdîk edilerek Evkâf Muhasebesi'ne gönderilmektedir. Böylece bir nüshası da İstanbul'a ulaşan kayıtlar sayesinde vakıfların gelir-gider, yönetim, görevli istihdâmı, sunulan hizmetlerin takibi mümkün olabilmekte idi. ${ }^{37}$

\section{Genel Değerlendirme}

Vakfın mali koşulları konusunda dikkate alınacak ilk gösterge cari dönem gelirlerinin seviyesidir. Cari dönem gelirleri yıllar itibari ile artış gösterirken, en fazla artış 1293/1876 yılındadır. Bu artışın temel nedeni vakfın köyü 'Ayn-1 Kârim'in 1292/1875 y1lından gelen öşür gelirleridir. Bunun yanı sıra kentsel gelirler arasında Meğaribe Mahallesi dışında bulunan vakıf musakkafât gelirleri ile vakfın Gazze'de bulunan akarlarından gelen gelirler bu artışta belirleyici olan diğer gelir kalemleri olmuştur.

Bu noktada üzerinde durulması gereken husus Ebu Medyen'in torunu Şuayb bin Muhammed bin el-Şuayb tarafından tamamı vakıf giderleri için vakfedilen 'Ayn-1 Kârim köyünün vakıf bütçesine olan ilk önemli katkısının bu yılda olmasıdır. Köyün öşür gelirlerinin kaydedildiği ikinci muhasebe kaydı 1317/18991900 tarihlidir. Buna göre köyün vakfa öşür geliri 20.416 kuruş 30 para ve Evkâf Sandığı'ndan köye ödenen öşür geliri de 3.431 kuruş 10 para olmuştur. Vakıf bütçesine oldukça mühim bir katkı sağlayan 'Ayn-1 Kârim köyünün öşür gelirlerinin neden düzenli bir şekilde katkı sağlamadığı ya da kaydedilmediği sorusu bu anlamda üzerinde durulması gereken bir sorudur. Başka bir çalışmada detaylı bir şekilde incelenecek olan bu şartlardan ilki vakıf gelirlerinin mîrî hazineye devredilerek, gelirlerin yalnızca 1/3'ünün vakıf bütçesine dâhil olduğuna dair Kudüs'ten İstanbul'a gönderilen şikâyetlerle açıklanabilir. ${ }^{38}$ Bunun yanı sıra bazı muhasebe defterlerinde de ifade edildiği üzere, 'Ayn-1 Kârim köyündeki bazı arsaların satış yolu ile özel mülkiyete dönüşmesi bir diğer gerekçe olarak değerlendirilebilir. ${ }^{39}$

37 Memiş, “18. Yüzyılda Kudüs’te”, s. 37-69.

38 Konuya ilişkin yapılan çalışma daha önce şurada sunulmuştur. Şerife Eroğlu Memiş, "Petitioning the Waqf Matters: Conflict Over Abu Madyan Waqf in Jerusalem at the Beginning of the Twentieth Century", World Congress for Middle Eastern Studies (WOCMES), Sevilla 2018.

39 Örn. bkz. İhyâu 't-Turâs Arşivi, Kutu No: 29, Dosya No:6/5/0/1328/13. 
Vakfın gelirleri arasında her yıl artan sayıda evin kiraya verilmesi vakıf bütçesi içinde mühim bir paya sahip olmuştur. Bu duruma paralel olarak vakıf giderleri arasında evlerin tamir ve bakım masrafları yıldan yıla artmıştır. Vakfın şehirdeki iktisadi etkilerinin görüleceği ilk aşama olarak bu inşa faaliyetleri değerlendirilebilir. Zira, inşaat bütçeleri ile çok sayıda vasıflı ve vasıfsız işgücüne istihdam sağlayan bu faaliyetler malzeme satınalımları ile de farklı üretici kesimleri ve tacirleri desteklemekte ve ekonomiye de canlılık getirmekte idi. Çoğunlukla Meğaribe Mahallesi'nde bulunan evlerden bir kısmı da Mağrib'den Kudüs'e gelen mücâvir ve misafirler için kiralanmakta ve kira bedeli de vakıf bütçesinden ödenmekteydi.

Vakfin dükkân, firın, değirmen ve sebze bahçelerinden elde ettiği gelirler vak1f bütçesi içinde yine önemli bir meblağ olmakla birlikte, vakfin evleri kadar mali durumunu temelden etkileyecek gelir kalemleri değildir. 1288/1871-1872 cari yılında sayıları artan dükkân kira gelirleri vakıf bütçesine önemli katkılar sağlamıştır.

Benzer şekilde vakfin hikr (mukâta'a) gelirleri de yine vakıf gelirleri arasında oldukça sınırlı bir katkıya sahiptir. Meğaribe Mahallesi'nde bulunan ve zemini vakfa ait evin mutasarrıfı el-Hac Mahmud Efendi el-Halidî ve sonrasında varisleri tarafından ödenen 200 kuruş hemen her muhasebe kaydında yer almıştır.

İncelediğimiz dönem içinde vakfin giderleri de yıldan yıla artış göstermiştir. Toplam giderlerdeki bu artış bir ölçüde sunulan hayır hizmetlerinin maliyetindeki ve vakıf musakkafâtının tamir ve bakımındaki artış ile ilişkilidir. Ebû Medyen Vakfi giderleri arasında ekmek ve yemek dağıtımı mühim bir orana sahip gider kalemidir. Mübarek üç aylardan Receb, Şaban ve Ramazan aylarında mahalle sakinlerine ekmek dağıtımı ile mahalle fakirlerine ve misafirlere Kudüs ziyaretleri esnasında yemek sunulması masrafları gider kalemleri arasında en fazla orana sahip hayır hizmetleridir. Bunları, Ramazan ve Kurban bayramlarında mücâvir olanlara sunulan yemek ve yine mücâvirlere vakfiye gereği okutulan mevlid sonrasında verilen yemek takip etmiştir. Muhasebe kayıtlarında belirtilmeyen önemli bir konu ise vakıftan yemek ya da ekmek alan kişi sayısıdır. Yıllar itibariyle fakir, misafir ya da mücâvir olarak mahallede kimlerin, ne kadar yemek ya da ekmek aldıklarına ilişkin herhangi bir bilgi bulunmamaktadır. Ancak muhasebe kayıtlarının yer aldığı bazı dosyalarda örneğin mahallede kendisine elbise dağıtılan Mağribliler çeşitli pusulalarda kaydedilmiştir. Yalnızca elbise ve kumaş dağıtılan kişilerin kaydedildiği bu pusulalar arasında ekmek ve yemek dağıtılan kişilere ilişkin herhangi bir listetespit edilememiştir. ${ }^{40}$

40 Çalışma çerçevesinde incelenen muhasebe kayıtlarının yer aldığı dosyada çok sayıda pusula örneği de mevcuttur. Bkz. İhyâu't-Turâs Arşivi, Kutu No:-, Dosya No: 45/2/1,19/47/13; Kutu No:-, Dosya No: 45/3/1,11/?/13. 
Konuya ilişkin bir başka detay ise vakıftan kış mevsiminde mahallede konaklayan mücâvirlere dağıtılmak için satın alınan elbise, kumaş, ayakkabı ya da mahallede üç aylarda dağıtılan ekmeğinihale usulü ile temin edilmesidir. ${ }^{41} \mathrm{Bu}$ hizmet alımlarına ilişkin ihale ilanı ve sonraki sürece ilişkin belgeler de yine vakfa ait çeşitli dosyalarda tespit edilmiştir. ${ }^{42} \mathrm{Bu}$ tür hizmet ve ürün alımları ile kentteki ekonomik etkinliğe direkt irtibat ve bağl1lık oluşturan koşullar yine vakfın ekonomisinin şehir ekonomisi ve şartları ile bağlantılarına da işaret etmesi bakımından önemlidir.

Hayrî bir vakıf olan Ebu Medyen Vakfı zâviyesinde kimsesiz vefat edenlerin kefen ve defin masraflarının karşılanması, yıl boyunca zâviyeye gelen ihtiyaç sahibi misafirlerin ihtiyaçlarının karşılanması, dönüş için seyahat harçlığı bulunmayanlara yol parası verilmesi gibi çeşitli yıllara ait muhasebe kaydı gider kalemlerinde kaydedilen hayrî hizmetler vakfin kuruluş gayesi çerçevesinde vakıf bütçesinde önemli gider kalemleri olarak kaydedilmiştir.

Vakıf giderleri arasında bazı yıllar ikinci sırada yer alan tamir masraflar1 1293/1876 y1lı giderleri arasında en yüksek sayıya ve meblağa ulaşmıştır. Vakıfların hizmet binaları olarak vakıf zâviyelerin tamir ve bakım, aydınlatma masrafları ile çoğunlukla Meğaribe Mahallesi'nde bulunan ev ve dükkân nev'inden gayrimenkulleri için üstlendikleri olağan ve düzenli tamir işleri yine vakfın şehir ekonomisi ile bağlılığına işaret etmektedir. Orbay, vakıfların bu tamir işleri ile aş ve yemek dağıtım süreçlerini bir "yeniden-dağıtım süreci" olarak değerlendirir. ${ }^{43}$

Vakfin personel sayısı ve giderlerinin uzun yıllar artmadan devam etmesi burada vurgulanması gereken başkaca önemli bir husustur. Vakfın görevli sayısı ancak yüzy1lın sonunada yani 1317/1899-1900 tarihli muhasebe kaydında önemli bir artış kaydetmiştir. Yine görevli sayısı belirtilmeden Ramazan ayında Meğaribe hafızlarının rubâ‘̂̂ okumaları görevi karşı1ığında 997 kuruş 10 para gibi bir artış da söz konusudur.

41 Memiş, "Sürdürülebilir Gelişmede", s. 78-85.

42 Abu Dîs'te yer alan arşiv dosyalarında çok sayıda munâkasa kaydı örneği de mevcuttur. Örn. bkz. İhyâu 't-Turâs Arşivi, Kutu No: 977, Dosya No: 45/3/1,1/21/13; Kutu No: 382, Dosya No: 24/3/0/4/1329/13.

43 Kayhan Orbay, "Vakfın Ekonomisi ve Yeniden Dağıtım", 22nd Symposium of International Committee of Pre-Ottoman and Ottoman Studies, cilt 1, Trabzon, 4- 8 Ekim 2016, s. 111-119. 


\section{Sonuç}

Kudüs'te Harem-i Şerîf' in batı duvarında Meğâribe ile Silsile kapıları arasında Mağribliler için kurulan Meğaribe Mahallesi’nde bulunan Ebu Medyen elĞavs'ın torunu Şuayb bin Muhammed bin el-Şuayb ve Şeyh Ömer el-Mücerred tarafindan vakfedilen zâviyeler, kuruluşlarından itibaren vakfiye şartları gereği çok çeşitli hizmetler sunmuşlardır. Bu vakıflarda, hayrî hizmetlerini yerine getirebilmek adına çok sayıda akar da vakfedilmiştir. Kentsel ve kırsal çeşitli gelir kaynaklarına sahip olan vakıflar, musakkafât ve müstegallât türünden akarlarının idamesi için yıllar boyunca çaba sarfetmişlerdir. Bu şekilde iktisadi ve ticari yaşamın altyapısına da katkılar sunan bu vakıfların en ciddi gelir kaynağını kentsel mülklerden alınan kira gelirleri oluşturmuştur. Bu anlamda, Kudüs şehri ekonomisi ile vakfın ekonomisi arasında da karşılıklı bir ilişki ağı kurulmuştur. Aynı karşılıklı bağımlılık kırsal ekonomide de mevcuttur. Çalışma kapsamında incelenen ve ancak bazı y1llara ait gelir kalemleri arasında tespit edilen tarımsal üretim neticesinde vakıf köydeki nüfustan alınan vergiler, vakfın yine en mühim gelir kaynağını oluşturmuştur. Bu ilişki ve bağlılık düzeyini göstermesi bakımından muhasebe kayıtları tafsilatlı bilgiler sunmuştur.

Son olarak, vakıf muhasebe kayıtlarından elde edilen bilgiler ve rakamlar 1şığında vakfın incelediğimiz yaklaşık yarım yüzyıllık dönem içinde ayırt edilebilir bir mali refah veya sıkıntı yaşayıp yaşamadığına bakabiliriz. Vakıf incelenen dönem boyunca faaliyetlerini aksatmadan sürdürmüştür. Kentsel gelirlerin artarak devam ettiği bazı yıllarda kırsal gelirlerin düşük kaldığı görülmüştür. Bazı yıllarda artan hayır hizmetleri ve tamirat masrafları nedeniyle vakıf cari y1lı sonraki yıla borç devrederek kapatmıştır. Bu mali sıkıntılara rağmen incelenen zaman diliminde vakfın uzun-dönemli ve vakfı sıkıntıya sokan bir mali bunalım yaşadığını söylemek mümkün gözükmemektedir. 


\section{Kaynakça}

\section{Arşiv Kaynakları}

İhyâu 't-Turâs ve'ş-Şuûni'd-Dîniyye Müessesetu İhyâi 't-Turâs ve'l-Buhûsi'lİslâmiyye Arşivi (İhyâu't-Turâs):

Kutu No: 41, Dosya No: 3/5/28/1271/13;

Kutu No: 06, Dosya No: 3/2/0/15/1318/13;

Kutu No:-, Dosya No: 45/2/1,19/47/13;

Kutu No:-, Dosya No: 45/3/1,11/?/13;

Kutu No: 977, Dosya No: 45/3/1,1/21/13;

Kutu No: 382, Dosya No: 24/3/0/4/1329/13;

Kutu No: 29, Dosya No: 6/5/0/1328/13.

Vakıflar Genel Müdürlüğü Arşivi (VGMA):

Defter No 583: Sayfa No 27/ Sira No 20; 583: 28/21; 515: 97/157; 515: 97/157.

\section{Kitap ve Makaleler}

Abowd, Tom, "The Moroccon Quarter: A History of the Present", Jerusalem Quarterly File (Institute of Jerusalem Studies), say1 7, 2000.

Arnon, Adar, "The Quarters of Jerusalem in the Ottoman Period", Middle Eastern Studies, cilt 28, say1 1, 1992.

Avc1, Yasemin, Değişim Sürecinde Bir Osmanlı Kenti, Kudüs (1890-1914), Ankara, Phoenix Yay., 2004.

Barkan, Ömer L., "Fatih Cami ve İmareti Tesislerinin 1489-1490 Y1llarına ait Muhasebe Bilançoları”, İstanbul Üniversitesi İktisat Fakültesi Mecmuası, cilt 23, say1 1-2, 1962-63.

, "İmaret Sitelerinin Kuruluş ve İşleyiş Tarzına Ait Araştırmalar", İstanbul Üniversitesi Iktisat Fakültesi Mecmuast, cilt 23, say1 1-2, 1962-63.

Ben-Arieh, Jehoshua, Jerusalem in the 19th Century: The Old City, Yad Izhak Ben Zvi, St. Martin Publications, 1984.

Cohen, Amnon, Osmanlı Kudüs'ünde Loncalar, çev. N. Elhüseyni, İstanbul, Tarih Vakfi Yurt Yay., 2003.

Cornell, Vincent J., The Way of Abu Madyan, Doctrinal and Poetic Works of Abū Madyan Shu 'ayb ibn al-Husayn al-Ansârī (c. 509/1115-16- 594/1198), Cambridge, The Islamic Texts Society, 1996. 
Durmuş, Muhammed Emin - Bektaş, İsmail, “Osmanlı'da Muhasebe Usulü ve Vakıf Muhasebe Kayıtları Okuma Kılavuzu",PESA Uluslararası Sosyal Araştırmalar Dergisi,cilt 3, sayı 2, 2017.

Erdoğdu, Akif, “Konya Mevlevi Dergâhının Mali Kaynakları ve İdaresi Üzerine Düşünceler ve Belgeler”, Belgeler, cilt XVII, sayı 21, 1996.

Faroqhi, Suraiya, "Vakıf Administration in Sixteenth Century Konya, The Zaviye of Sadreddin-i Konevi", Journal of the Economic and Social History of the Orient, cilt XVII, say1 2, 1974.

, "A Great Foundation in Difficulties: or some evidence on economic contraction in the Ottoman Empire of the mid-seventeenth century", Revue D'Histoire Magrebine, cilt 47-48, 1987.

Genç, Mehmet, “Klasik Osmanlı Sosyal-İktisadi Sistemi ve Vakıflar', Vakıflar Dergisi, say1 42, 2014.

Güneş, Hasan H., Kudüs Meğaribe Mahallesi, Ankara, VGM Yay., 2017. , "Kudüs’te Bir Mahalle: Sekiz Yüz Yıllık Meğaribe Mahallesi ve Serencamı", Vakıflar Dergisi, say1 44, 2015.

Güvemli, Oktay - Güvemli, Batuhan, “Osmanlı Kayıt Kültüründe Vakıf Muhasebesi ve Devlet Muhasebe Sistemi”, Vakıflar Dergisi, sayı 46, 2016.

Ğuşe, Muhammed Haşim, el-Evkâfu'l-İslâmiyye fi'l-Kudsi'-ş-Şerîf: Dirâse Târihiyye Muvesseka, İstanbul, IRCICA, 2009.

el-Hanbelî, Mucireddin el-'Uleymî,el-Unsü'l-celîl fî Târih-i Kuds ve'l-Halîl, cilt II, Amman, Mektebetu'l-Muhtesib, 1973.

Harekât, İbrahim, "Mağrib” Mad.,TDV İslam Ansiklopedisi, cilt 27, 2003.

el-Jubeh, Nazmi, Hâret el-Yehud ve hâret el-Magharibe fì el-Kuds el-Kadîme: el-târîh ve el-masîr ma beyne el-tadmîr ve el-tahvîd, Beyrut, Institute for Palestine Studies, 2019.

Köprülü, Fuat, 'Vakıf Müessesesi ve Vakıf Vesikalarının Tarihi Ehemmiyeti', Vakıflar Dergisi, say1 1, 1938.

Little, Donald P., "Jerusalem under the Ayyubids and Mamluks, 1187-1516 AD”, içinde Jerusalem in History, ed. Kamil C. el-Aseli, Brooklyn, NY, 1990.

Memiş, Şerife E.,"18. Yüzyılda Kudüs'te Meğâribe Mahallesi Vakıflarının Yönetimi ve Görevli İstihdamı”, Journal of Islamicjerusalem Studies, cilt 17, say1 1, 2017. 
, "Between Ottomanisation and Local Networks: Appointment Registers as Archival Sources for Waqf Studies. The Case of Jerusalem's Maghariba Neighborhood", Ordinary Jerusalem 1840-1940, Openning New Archives, Revisiting a Global City, ed.Angelos Dalachanis - Vincent Lemire, Leiden, Brill, 2018.

, "Petitioning the Waqf Matters: Conflict Over Abu Madyan Waqf in Jerusalem at the Beginning of the Twentieth Century", World Congress for Middle Eastern Studies (WOCMES), Sevilla, 2018.

, "Sürdürülebilir Gelişmede Vakıfların Tarihi Rolü: Ebû Medyen el-Ğavs Zâviyesi”, Keşkül Dergisi,sayı 46, 2018.

el-Mübeyyid, Selim Arafat, El-Binâyât el-Eseriyye el-İslâmiyye fí Gazze ve kıtâihâ, Kahire, el-Hay'a el-Misriyye el- 'Âmma li'l-Kitâb, 1987.

O’Neil, Maryvelma S., "The Mughrabi Digital Archive and the Virtual Illes Relief Initiative", Jerusalem Quarterly, no. 81, Bahar 2020.

Orbay, Kayhan, "16. ve 17. Yüzy1llarda Bursa Ekonomisi: Sultan Çelebi Mehmed Yeşil İmaret'inin Mali Tarihi (1553-1650)”, A.Ü. Osmanlı Tarihi Araştırma ve Uygulama Merkezi (OTAM) Dergisi, sayı 22, Güz 2007.

,"Structure and the Content of the WaqfAccount Books as sources for Ottoman Economic and Institutional History", Turcica, Revue D'Etudes Turques, cilt 39, 2007.

, "Vakfın Ekonomisi ve Yeniden Dağıtım", 22nd Symposium of International Committee of Pre-Ottoman and Ottoman Studies, cilt 1, Trabzon, 4-08 Ekim 2016.

Salenson, Irène - Lemire, Vincent, "La destruction du quartier des Maghrébins: entre histoire, urbanisme et archéologie (1967-2007)", Les Cahiers de l'Orient, vol. 130, no. 2, Spring 2018.

Şensoy, Fatma, “Ebubekir Paşa'nın İstanbul'daki Sıbyan Mektebi ve Sebil Vakfi'nın 1867-68 Yıllarına ait Muhasebe Defterleri Üzerinden Vakıflardaki Kayıt Düzeni ve Dinamik Yapı”, Akademik Incelemeler Dergisi, cilt 13, sayı 1, 2018.

Tamari, Salim, "Waqf Endowments in the Old City of Jerusalem: Changing Status and Archival Sources", içinde Ordinary Jerusalem 1840-1940, Openning New Archives, Revisiting a Global City, ed. Angelos Dalachanis - Vincent Lemire, Leiden, Brill, 2018.

Tibawi, Abdüllatif, The Islamic Pious Foundations in Jerusalem, Origins, History, and Usurpation by Israel, London, The Islamic Culture Centre, 1978. 
Yediyıldız, Bahaeddin, "Vakıf”, MEB İslam Ansiklopedisi, cilt 13, 1986. ,"Müessese-Toplum Münasebetleri Çerçevesinde XVIII. Asır Türk Toplumu ve Vakıf Müessesesi”, Vakıflar Dergisi, sayı 15, 1982.

Zarcone, Thierry, Kudüs'teki Orta Asyalı ve Hintli Sufi Hacılar, çev. Berna Akkıyal, İstanbul, Kabalcı Yay., 2012.

Ze'evi, Dror, Kudüs:17. Yüzyılda Bir Osmanlı Sancağında Toplum ve Ekono$m i$, çev. S. Çağlayan, İstanbul, Tarih Vakfi Yurt Yay., 2000. 
